\title{
Article
}

\section{Redox Processes impacting the flux of Fe(II) from shelf sediments to the OMZ along the Peruvian shelf}

\author{
Peter L. Croot, Maija I Heller, and Kathrin Wuttig \\ ACS Earth Space Chem., Just Accepted Manuscript • DOI: 10.1021/ \\ acsearthspacechem.8b00203 • Publication Date (Web): 19 Feb 2019
}

Downloaded from http://pubs.acs.org on February 22, 2019

\section{Just Accepted}

"Just Accepted" manuscripts have been peer-reviewed and accepted for publication. They are posted online prior to technical editing, formatting for publication and author proofing. The American Chemical Society provides "Just Accepted" as a service to the research community to expedite the dissemination of scientific material as soon as possible after acceptance. "Just Accepted" manuscripts appear in full in PDF format accompanied by an HTML abstract. "Just Accepted" manuscripts have been fully peer reviewed, but should not be considered the official version of record. They are citable by the Digital Object Identifier (DOI®). "Just Accepted" is an optional service offered to authors. Therefore, the "Just Accepted" Web site may not include all articles that will be published in the journal. After a manuscript is technically edited and formatted, it will be removed from the "Just Accepted" Web site and published as an ASAP article. Note that technical editing may introduce minor changes to the manuscript text and/or graphics which could affect content, and all legal disclaimers and ethical guidelines that apply to the journal pertain. ACS cannot be held responsible for errors or consequences arising from the use of information contained in these "Just Accepted" manuscripts. 


\title{
Redox processes impacting the flux of $\mathrm{Fe}(\mathrm{II})$
}

\section{from shelf sediments to the $\mathrm{OMZ}$ along the}

\section{Peruvian shelf}

\author{
Peter L. Croot ${ }^{1,2}$, Maija I. Heller ${ }^{2,3}$ and Kathrin Wuttig ${ }^{2,4}$. \\ 1iCRAG (Irish Centre for Research in Applied Geoscience), Earth and Ocean Sciences, \\ School of Natural Sciences and the Ryan Institute, National University of Ireland \\ Galway, Galway, Ireland. \\ ${ }^{2}$ FB2: Marine Biogeochemistry, GEOMAR Helmholtz Centre for Ocean Research, Kiel, \\ D-24105, Germany. \\ ${ }^{3}$ Escuela de Ciencias del Mar, Facultad de Recursos Naturales, Pontifica Universidad \\ Católica de Valparaíso, Valparaíso, Chile. \\ ${ }^{4}$ Antarctic Climate \& Ecosystems Cooperative Research Centre (ACE CRC), University \\ of Tasmania, Private Bag 80, Hobart, Tasmania 7001, Australia.
}

\section{ORCID iD:}

Peter Croot 0000-0003-1396-0601

Maija Heller 0000-0002-1258-8660

Kathrin Wuttig 0000-0003-4010-5918

For submission to ACS Earth \& Space Chemistry special issue 


\begin{abstract}
:
Iron $(\mathrm{Fe})$ is a limiting nutrient in many regions of the open ocean and can also play a key role in controlling primary productivity in Eastern Boundary Upwelling Systems (EBUS). In EBUS regions, where intense Oxygen Minimum Zones (OMZs) contact the continental shelf, significant iron inputs can result from the supply of Fe(II) from reducing sediments. How much of this iron makes it to the photic zone depends on physical processes mixing over different time scales (minutes to decades) and the kinetics of redox and complexation processes impacting the biogeochemical cycling of iron. In this work we examine the controls on Fe(II) release from shelf sediments across the Peruvian $\mathrm{OMZ}$ by measuring $\mathrm{Fe}(\mathrm{II})$ and $\mathrm{H}_{2} \mathrm{O}_{2}$ in the water column and benthic boundary layer (BBL) and applying a simple 1D mixing model, with either 1 or 2 layers, where the flux of $\mathrm{Fe}(\mathrm{II})$ to the water column is treated as analogous to radon, that the decay rate is constant within the mixing layer. Our modelling approach then allows us to compare our estimated decay rate against published oxidation rates for specific oxidants of $\mathrm{Fe}(\mathrm{II})$ in OMZ waters and check the validity of our approach. Our data indicate that throughout the OMZ, $\mathrm{Fe}(\mathrm{II})$ decay rates may be partially influenced by $\mathrm{H}_{2} \mathrm{O}_{2}$, but that it is most likely that nitrate-dependent anaerobic Fe(II) oxidizing (NDFO) bacteria are the main oxidizers. In the secondary nitrite maxima (SNM), abiotic $\mathrm{NO}_{2}^{-}$or biotic mediated processes may also be important. This work highlights the importance and uses of redox species in understanding biogeochemical cycles in the ocean.
\end{abstract}

Keywords: $\mathrm{H}_{2} \mathrm{O}_{2}, \mathrm{ROS}, \mathrm{NDFO}$, Nitrite, Nitrate, $\mathrm{BBL}$. 


\section{Introduction}

Understanding and interpreting the distribution of elements in the ocean, and perhaps more importantly the biogeochemical and redox processes that drive the observed distribution, is a major goal of chemical oceanographers today. An important step towards this goal is the identification and quantification of processes occurring in the ocean over differing spatial and temporal scales as data on this is vital for correctly interpreting the impact of chemical and biological processes occurring. Redox processes involving iron are an important part of the biogeochemical cycling of iron ${ }^{1}$ and other elements in the ocean ${ }^{2}$ thus improving our ability to model iron chemistry in the oceans is critical for Earth system models ${ }^{3}$. However deciphering iron redox cycling in the ocean are more complicated than in sediment systems as the observed signals are the results of abiotic and biotic processes superimposed on a mixing ocean varying both spatially and temporally. Over the last 30 years the use of chemical tracers for studying mixing processes has undergone considerable evolution since the first ground breaking studies using CFCs were published ${ }^{4,5}$, measurements now include multiple tracers (e.g. $\left.\mathrm{CFCs},{ }^{3} \mathrm{He},{ }^{129} \mathrm{I}\right)$ with different lifetimes and sources, leading to the development of concepts such as the tracer age of a water mass ${ }^{6}$. Thus, in the context of international research programs such as GEOTRACES (www.geotraces.org), SOLAS (solas-int.org) and IMBER (www.imber.info $)$ information on redox and mixing processes is critical to improving our understanding of biogeochemical cycles in the ocean.

One group of chemical tracers that has so far been underutilized are the transient redox species that exist in the ocean. These are chemical species which while being thermodynamically unfavoured under seawater conditions may exist over a range of 
different temporal scales due to kinetic limitations. In many cases the reduction step might be relatively quick but reoxidation (e.g. $\mathrm{H}_{2} \mathrm{O}_{2}, \mathrm{Fe}(\mathrm{II})$ and $\mathrm{I}^{-}$) or further reduction (e.g. $\mathrm{H}_{2} \mathrm{O}_{2}$ ) may take some time to occur ${ }^{7,8}$. Recent advances in analytical chemistry have seen the development of new methods specific for the determination of redox chemical species at open ocean concentrations paving the way for their application to use as tracers ${ }^{9}$. A further key requirement for a useful transient redox tracer is information on the processes that control the conversion rate (oxidation or reduction) of the specific tracer. A major controlling factor for the speciation of many of these redox species is the concentration of dissolved oxygen $\left(\mathrm{O}_{2}\right)$ and thus a natural laboratory for examining these tracers is in oxygen minimum zones (OMZ) ${ }^{10}$.

Analysis of time series data indicate that OMZs are expanding ${ }^{11}$ and this may result in an expansion of the distribution of redox sensitive species with resulting changes in the biogeochemical cycles of these elements ${ }^{12,13}$. Recent work in OMZs and anaerobic zones suggest strong coupling between the $\mathrm{Fe}$ and $\mathrm{N}$ biogeochemical cycles; via chemodenitrification, where nitrite oxidises $\mathrm{Fe}(\mathrm{II})$ and is converted to $\mathrm{N}_{2} \mathrm{O}$, and by the microbially mediated nitrate-dependent anaerobic Fe(II) oxidation (NDFO) ${ }^{14,15}$. Anaerobic ammonium oxidation coupled to Fe(III) reduction (Feammox) ${ }^{16}$ has been found in soils but not yet the ocean. Nitrate oxidation of Fe(II) has also been considered as possibly supporting life on Mars ${ }^{17}$. The balance between microbial and abiotic oxidation rates for $\mathrm{Fe}(\mathrm{II})$ has implications for both our present day understanding of $\mathrm{Fe}$ cycling and that of the past ${ }^{18}$. Thus, there are several compelling reasons to investigate the chemistry of transient redox tracers such as Fe(II) in OMZ waters. In the present work we report data on the vertical distribution of Fe(II) effluxed from reducing sediments into 
the bottom waters in an OMZ region and examine potential processes controlling its distribution.

\subsection{Mixing at Ocean boundaries.}

Information on mixing processes in the surface ocean is critical to understanding the distribution and biogeochemical cycling of bio-important elements such as Fe. Vertical mixing in the ocean occurs over a range of spatial and temporal scales ${ }^{19}$ and is an important constraint on the supply of nutrients and the exposure to light for phytoplankton ${ }^{20}$. Temporal variability in the processes affecting the surface ocean has seen the development of two terms to describe the surface mixed layer ${ }^{21}$ : (i) The Active Mixing Layer (AML) is defined as the depth zone which is actively mixed from the surface at a given time and generally corresponds to a zone where strong surface forcing induces turbulent mixing. (ii) The Mixed Layer Depth (MLD) is the maximum depth reached by the AML on time scales of 24 hours or more.

Early work on the mixing in the upper ocean were based on temperature or density profiles obtained using a conventional CTD and analysed in terms of Thorpe displacements ${ }^{22}$. The recent development of microstructure profilers ${ }^{23}$ has led to improvements in the measurements of the turbulence in the upper ocean. Additional approaches have used tracer release experiments using $\mathrm{SF}_{6}$ or high resolution velocity measurements made by a shipboard mounted acoustic doppler current profiler (ADCP) data to determine velocity shear this results in a number of approaches by which diffusion and mixing processes can be assessed in the upper ocean ${ }^{24-29}$. 
The other boundary to the water column is the interface with the sediment. Here similar terms exist for the mixing zones adjacent to the ocean bottom. The benthic or bottom boundary layer (BBL) is the region adjacent to the ocean bottom ${ }^{30}$, and in this region chemical and physical properties can be distinct from the overlying ocean interior 31. Turbulent boundary layer flow ${ }^{32}$ in the BBL induces the formation of a bottom mixed layer (BML), which is typically $15-60 \mathrm{~m}$ in height ${ }^{33}$. The BML is in many ways analogous to the surface AML, and is the zone through which benthic-pelagic coupling of biogeochemical cycles can occur, as the surface AML is for air/sea interactions.

Waters close to the sediment in the ocean have historically been assessed using light scattering (nephelometry) and are typically described by the following terms ${ }^{34}$ : bottom nepheloid layer (BNL), which can extend up to $2000 \mathrm{~m}$ and the bottom mixed nepheloid layer (BMNL) and which is equivalent to the BML. Above the BMNL there is an approximately logarithmic fall-off in the intensity of light scattering up to the clearest water minimum that indicates the top of the BNL. Along continental margins, intermediate nepheloid layers (INL) can be found and they result from interactions on the upper continental slope and at the depth of the shelf edge and may extend out across the continental margin ${ }^{35}$. Determining mixing rates in the BBL is perhaps more complicated than in the AML as microstructure sensors are limited in their application here, instead recent work on mixing in the BBL have looked at different approaches to estimating turbulent diffusion in this region ${ }^{31}$ and employed specialized sampling devices to obtain samples in the BML ${ }^{36}$.

The effect of turbulent mixing on the distribution of a chemical species can be simply described as quasi diffusive transport according to Fick's law of diffusion: 


$$
J=-K_{Z} \frac{\partial C}{\partial z}
$$

Where $\mathrm{J}$ is the flux through the water column, $K_{\mathrm{Z}}$ is the diffusion coefficient, $\mathrm{C}$ the concentration of the chemical species and $\mathrm{z}$ the depth. Modelling of the physical processes in the AML has evolved from the diel cycle studies of the Price-Weller-Pinkel (PWP) model ${ }^{37}$ to the present day use of turbulent closure approaches ${ }^{38}$ which form the basis of the 1D General Ocean Turbulence model (GOTM) model (www.gotm.net) which has been applied to iron redox processes in the surface ocean ${ }^{39}$. Iron may be thought of as an unlikely tracer due to its particle reactivity and non-conservative behaviour in seawater, however total Fe has been used previously as a mixing tracer in an iron enrichment experiment ${ }^{40}$ giving values similar to microstructure measurements ${ }^{24}$. In the present work our aim was not to examine the mixing modelling approaches in detail but to focus on the chemical processes involved and evaluate the suitability of this approach to transient redox tracers for use in biogeochemical modelling studies.

\subsection{Iron speciation and supply to the photic zone from sediments}

In oxygenated seawater $\mathrm{Fe}(\mathrm{III})$ is the dominant redox species, as while $\mathrm{Fe}(\mathrm{II})$ is more soluble than $\mathrm{Fe}(\mathrm{III})$ at alkaline $\mathrm{pH}, \mathrm{Fe}(\mathrm{II})$ is rapidly oxidized by reactive oxygen species (ROS), principally $\mathrm{O}_{2}$ and $\mathrm{H}_{2} \mathrm{O}_{2}{ }^{41,42}$, with the short lived radical species $\mathrm{O}_{2}^{-}$and $\mathrm{OH}$ are also involved. However in seawater Fe(III) is poorly soluble and is rapidly hydrolysed resulting in the formation of various $\mathrm{Fe}(\mathrm{III})$ oxyhydroxide phases with differing chemical reactivities ${ }^{43}$. Dissolved Fe(III) is strongly complexed by organic chelators in seawater ${ }^{44,45}$, most likely produced by bacteria or phytoplankton, which overall increase the solubility of iron ${ }^{46}$. The reduction of $\mathrm{Fe}(\mathrm{III})$ to $\mathrm{Fe}(\mathrm{II})$ by 
photochemical or other processes is a possible mechanism by which colloidal iron is made more bioavailable to phytoplankton 47 , 48 . In tropical waters, $\mathrm{Fe}(\mathrm{II})$ is viewed as a short lived intermediate in iron cycling ${ }^{49}$, existing at low concentrations (pM or less), however during spring blooms in colder coastal waters Fe(II) has been detected at elevated concentrations $(\sim 1 \mathrm{nM}){ }^{50}$. More recently significant concentrations of Fe(II) have been detected at depth in the sub-oxic waters of oxygen minimum zones ${ }^{51-53}$. Continental shelf sediments can be a significant source of iron, through simple resuspension and mixing, to the overlying water column ${ }^{54,55}$ and a primary source of iron for phytoplankton ${ }^{56}$. In EBUS regions, where an OMZ interacts with the continental shelf, iron fluxes can be considerably enhanced ${ }^{57-59}$ and lead to what Bruland et al. termed the Blue and Brown waters of Peru ${ }^{59}$, where inshore high iron concentrations helped to supply large phytoplankton blooms fuelled by upwelling waters, while offshore waters were low in iron and optically very clear with little phytoplankton activity. In this context the cross shelf transport of iron is also important, and recent work has shown that in the Peru OMZ there is considerable mesoscale eddy activity ${ }^{60,61}$ and that these eddies reduce biological activity inshore ${ }^{62}$ while increasing offshore activity and impacting $\mathrm{N}$ cycling there ${ }^{63,64}$. Along the Peruvian continental shelf, significant concentrations of Fe(II) have been detected previously in the water column ${ }^{53,65,66}$ and were associated with nitrite maxima and/or benthic sources. Similarly a well-defined INL was found previously along the Peruvian coast with a particle maximum at $200 \mathrm{~m}{ }^{67}$ and was associated with the nitrite maxima within the core of the OMZ.

Sediment porewaters are typically lower in $\mathrm{pH}$ and oxygen than the overlying seawater resulting in an environment that favours Fe(II) this leads to the iron flux from 
the sediments being predominantly Fe(II) ${ }^{68,69}$ and fluxes increasing with decreasing oxygen concentrations ${ }^{70}$. There is some data suggesting sediments are also a source of iron binding ligands ${ }^{71,72}$ to the water column, oxidation of the $\mathrm{Fe}(\mathrm{II})$ and subsequent complexation of $\mathrm{Fe}(\mathrm{III})$ has been proposed as a mechanism by which the flux of iron from the sediment could be mixed further through the water column ${ }^{73}$. How far the iron is transported than is a balance between the kinetics of oxidation, complexation and scavenging on to particles that are then sedimented out, processes that occur in the AML 74 as well as the BBL.

\subsection{Oxidation kinetics of $\mathrm{Fe}(\mathrm{II})$ in seawater}

There have been a number of laboratory studies undertaking precise measurements of $\mathrm{Fe}(\mathrm{II})$ oxidation rates in seawater at $\mathrm{nM}$ levels $41,42,75-79$. However the measurement of Fe(II) in the open ocean is complicated by low concentrations $(<100$ $\mathrm{pM}$ ) and the potential for artefacts induced by the analytical method employed ${ }^{80}$. The recent development of flow injection chemiluminescence techniques ${ }^{81}$ now permits studies into the speciation and cycling of Fe(II) in natural waters with minimal sample perturbation. There are only a few measurements of $\mathrm{Fe}(\mathrm{II})$ oxidation rates at low $\mathrm{O}_{2}$ concentrations ${ }^{82-84}$ and deviations from the rate laws found at higher $\mathrm{O}_{2}$ concentrations are thought to be due to $\mathrm{H}_{2} \mathrm{O}_{2}$ being the dominant oxidant and back reactions between $\mathrm{Fe}(\mathrm{III})$ and $\mathrm{O}_{2}^{-} \cdot \mathrm{H}_{2} \mathrm{O}_{2}$ has previously been shown to be a key oxidant for $\mathrm{Fe}(\mathrm{II})$ in Antarctic waters ${ }^{8}$. Table 1 summarizes data on Fe(II) oxidation rates in the literature that is of relevance to the present study. 
In the absence of ROS species, attention more recently has focused on $\mathrm{Fe}(\mathrm{II})$ oxidation by $\mathrm{NO}_{\mathrm{X}}$ species in abiotic and biotically mediated pathways ${ }^{85}$. The abiotic oxidation of $\mathrm{Fe}(\mathrm{II})$ by $\mathrm{NO}_{3}{ }^{-}$in the absence of $\mathrm{O}_{2}$ has been found in earlier studies to have a maximum rate around $\mathrm{pH} 8^{86,87}$ and while it is slower than oxidation by $\mathrm{NO}_{2}{ }^{-}$at neutral $\mathrm{pH}$, it is efficiently catalysed by $\mathrm{Cu}^{88}$. Contrastingly $\mathrm{Cu}$ was not found to catalyse the reaction between $\mathrm{NO}_{2}{ }^{-}$and $\mathrm{Fe}(\mathrm{II})$ at $\mathrm{pH} 8$ but did alter the ratio of the products, $\mathrm{N}_{2} \mathrm{O}$ and $\mathrm{N}_{2}{ }^{89}$. Heterogeneous reactions involving Fe(II) containing minerals (e.g. nontronite or green rust) have been shown to be very important as they can catalyse the reaction with $\mathrm{NO}_{2}{ }^{-90}$. Recent works have focused on identifying and quantify the processes involved during $\mathrm{Fe}(\mathrm{II})$ oxidation by NDFO bacteria in order to assign biotic and abiotic rates as at the high concentrations of Fe(II) typically employed the heterogeneous reactions may mask any microbial oxidation 91,92 .

\subsection{Application of $\mathrm{Fe}(\mathrm{II})$ as a tracer in the BBL of $\mathrm{OMZ}$ waters}

In regions where the $\mathrm{OMZ}$ overlies the continental shelf or slope, $\mathrm{Fe}(\mathrm{II})$ diffusing from the sediments may persist for some time due to the low $\mathrm{O}_{2}$ concentrations present there. Under the conditions of constant $\mathrm{O}_{2}$ concentrations in the $\mathrm{OMZ}$ and in the absence of significant advective transport the vertical distribution of Fe(II) may be considered analogous to the release of radon from the sediments if it is assumed that there is a constant decay rate. Radon has been used in a number of studies to determine mixing rates in the $\mathrm{BBL}^{93-96}$. A brief outline of the approach is given below: 
The OMZ waters in the BBL above the sediment are assumed to have constant temperature, $\mathrm{pH}$, salinity and that the decay rate for $\mathrm{Fe}(\mathrm{II}), \lambda$, is constant throughout the $\mathrm{BBL}$ and can be considered analogous to the half-life of a radiotracer such as ${ }^{222} \mathrm{Rn}$.

$$
\lambda=k_{O 2}\left[\mathrm{O}_{2}\right]+k_{\mathrm{H} 2 \mathrm{O} 2}\left[\mathrm{H}_{2} \mathrm{O}_{2}\right]+\ldots
$$

Where $k_{\mathrm{O} 2}$ and $k_{\mathrm{H} 2 \mathrm{O} 2}$ are the calculated rates constants for the oxidation of Fe(II) by $\mathrm{O}_{2}{ }^{42}$ and $\mathrm{H}_{2} \mathrm{O}_{2}{ }^{41}$ respectively, other terms for $\mathrm{NO}_{2}{ }^{-}$or $\mathrm{NO}_{3}{ }^{-}$mediated oxidation could also be include (see Table 1 for details). Under the conditions of constant vertical diffusivity $\left(K_{\mathrm{Z}}\right)$ in the BBL the vertical distribution of $\mathrm{Fe}(\mathrm{II})$ (denoted below as $\mathrm{C}$ ) can be formulated as follows ${ }^{94,97}$ :

$$
K_{Z} \frac{\partial^{2} C}{\partial^{2} Z}-\lambda C=0
$$

\subsubsection{Single layer model}

This simple differential equation can be solved using a simple set of boundary conditions;

(i) Sediment/Water interface: $C=C_{0}$ at $\mathrm{z}=0$, (ii) Top of the water column: $\mathrm{C} \rightarrow 0$ as $\mathrm{z} \rightarrow \infty$. Gives the following solution

$$
C=C_{0} e^{-z \sqrt{\frac{\lambda}{K_{Z}}}}()
$$

The flux ( $\mathrm{J})$ of $\mathrm{Fe}(\mathrm{II})$ at the sediment water interface can be related to $C_{0}$ as follows

$$
J=-K_{Z} \frac{\partial C}{\partial z_{Z}=0}
$$

which then reduces to

$$
J=C_{0} \sqrt{K_{Z} \lambda}
$$

The steady state inventory of $\mathrm{Fe}(\mathrm{II})$ in the water column, $\left(\mathrm{I}_{\mathrm{ss}}\right)$, from the benthic source can also be described:

$$
I_{S S}=\int_{z=0}^{z=\infty} C \partial z
$$


which leads to the following relationship

$$
I_{s S}=\frac{J}{\lambda}=C_{0} \sqrt{\frac{K_{Z}}{\lambda}}
$$

Thus the steady state inventory of Fe(II) is related to the flux from the sediment and the half-life for $\mathrm{Fe}(\mathrm{II})$ in the overlying waters. Knowledge of one of these variables (e.g. the flux from sediment porewater profiles or in situ measurements of the decay rate) will allow the calculation of the other. Similarly, rearranging equation 8 allows a solution for $K_{\mathrm{Z}}$

$$
K_{Z}=\frac{J^{2}}{\lambda C_{0}^{2}}
$$

Alternatively, a value of $K_{Z}$ can be estimated by relationships to the inverse of the buoyancy frequency $(N)^{27,96}$ or via other tracers.

\subsubsection{Two layer model}

The two layer model originates from the Air/Sea interface radon model of Peng et al. ${ }^{98}$ which was applied to benthic fluxes of radon by Sarmiento et al. ${ }^{96}$. In this case we designate the layer closest to the sediment as layer 2, with thickness $\mathrm{D}$, and that in the interior as layer 1 . As above $\lambda$ denotes the decay rate of $\mathrm{Fe}(\mathrm{II})$, with $K_{\mathrm{i}}$ and $\lambda_{\mathrm{i}}$ the vertical diffusivity and $\mathrm{Fe}(\mathrm{II})$ decay rate in each layer respectively.

Thus, the equation for the upper layer (layer 1) is

$$
C_{1}=C_{D} e\left(\frac{-(z-D)}{\sqrt{\frac{K_{1}}{\lambda_{1}}}}\right)
$$

Where $C_{\mathrm{D}}$ denotes the concentration at the interface between layer 1 and 2 . The equation for the lower layer is 


$$
C_{2}=\frac{C_{D}}{2}\left(1+\frac{\sqrt{\frac{K_{1}}{\lambda_{1}}}}{\sqrt{\frac{K_{2}}{\lambda_{2}}}}\right) e\left(\frac{-(z-D)}{\sqrt{\frac{K_{2}}{\lambda_{2}}}}\right)+\frac{C_{D}}{2}\left(1-\frac{\sqrt{\frac{K_{1}}{\lambda_{1}}}}{\sqrt{\frac{K_{2}}{\lambda_{2}}}}\right) e\left(\frac{(z-D)}{\sqrt{\frac{K_{2}}{\lambda_{2}}}}\right)
$$

We simplify here by using the term $a_{\mathrm{i}}=\sqrt{ }\left(\mathrm{K}_{\mathrm{i}} / \lambda_{\mathrm{i}}\right)$ for each layer.

$$
C_{2}=\frac{C_{D}}{2}\left(1+\frac{a_{1}}{a_{2}}\right) e\left(\frac{-(z-D)}{a_{2}}\right)+\frac{C_{D}}{2}\left(1-\frac{a_{1}}{a_{2}}\right) e\left(\frac{(z-D)}{a_{2}}\right)
$$

The concentration at the sediment water interface is then

$$
C_{0}=\frac{C_{D}}{2}\left(1+\frac{a_{1}}{a_{2}}\right) e\left(\frac{D}{a_{2}}\right)+\frac{C_{D}}{2}\left(1-\frac{a_{1}}{a_{2}}\right) e\left(\frac{-D}{a_{2}}\right)
$$

The flux throughout the water column is then:

$$
\begin{gathered}
J=K_{2}{\frac{\partial C}{\partial z_{Z}}}_{z=0} \\
J=-K_{2} \frac{C_{D}}{2 a_{2}}\left(\frac{a_{1}}{a_{2}}+1\right) e\left(\frac{(D-z)}{a_{2}}\right)-K_{2} \frac{C_{D}}{2 a_{2}}\left(\frac{a_{1}}{a_{2}}-1\right) e\left(\frac{-(D-z)}{a_{2}}\right)
\end{gathered}
$$

Thus at the boundary where $z=0$ :

$$
J=-K_{2} \frac{C_{D}}{2 a_{2}}\left(\left(\frac{a_{1}}{a_{2}}+1\right) e\left(\frac{D}{a_{2}}\right)+\left(\frac{a_{1}}{a_{2}}-1\right) e\left(\frac{-D}{a_{2}}\right)\right)
$$

See the S.I. for this manuscript for more details on the derivation of the steady state concentration. A key observation here is that it is not possible as in the $1 \mathrm{D}$ case to separate the oxidation rate from the diffusive mixing rate using the steady state concentration as the number of unknowns has increased to 5 (or 6 if you solve also for D). However as for the $1 \mathrm{D}$ case this could be reduced to 3 unknowns if estimates of $\mathrm{K}_{\mathrm{i}}$ are made using other approaches, though in practice with a well-mixed BBL, fitting of $\mathrm{K}_{2}$ only provides a lower bound for the mixing rate.

\section{Experimental Section}

\subsection{Study sites}




\subsubsection{Benthic-Pelagic coupling on the Peruvian shelf}

The study area considered in this work was the OMZ off the coast of Peru. Results are presented for the RV Meteor M77-1, Talcahunao, Chile to Callao, Peru (Oct 23 - Nov 21, 2008) an expedition which focused on benthic-pelagic coupling on the Peruvian shelf between $10^{\circ}$ and $12^{\circ} \mathrm{S} 99,100$.

\subsection{Analytical Measurements}

\subsubsection{Dual measurement of $\mathrm{Fe}(\mathrm{II})$ and $\mathrm{H}_{2} \mathrm{O}_{2}$}

Seawater samples were obtained either using Niskin bottles on a standard Seabird CTD and rosette. A key element of this study was sampling close to the sediment using the CTD and this was accomplished successfully to within 1-2 $\mathrm{m}$ above the bottom by virtue of a well calibrated altimeter and stable weather conditions with minimal swell. Niskin bottles were checked for gas leaks prior and after each deployment. In this study samples were drawn first (before any other samples) from the Niskin bottles into brown high density polyethylene (HDPE) bottles (Nalgene) using a silicone tube in the same manner as for low level dissolved $\mathrm{O}_{2}{ }^{101}$ with no headspace or bubbles in the samples. HDPE bottles are significantly less oxygen permeable than LDPE or Teflon. Use of clear glass bottles is avoided due to the potential for photoreduction of Fe and/or photoformation of $\mathrm{H}_{2} \mathrm{O}_{2}$. Samples were analyzed in triplicate, within 1-2 hours of collection and were unfiltered. All sampling and analysis was performed in a trace metal clean laminar flow cabinet (AirClean Systems).

Fe(II) was determined using a modified version of an existing chemiluminescence method ${ }^{81}$. In brief the system was adapted to run $\mathrm{Fe}(\mathrm{II})$ and $\mathrm{H}_{2} \mathrm{O}_{2}$ simultaneously on the 
same machine by continuously running sample to the detector and using an injection valve to separate the two independent reagent flows which had been prepared as described previously. This differs from the usual setup employed for Fe(II) as previously it was run in sample injection mode and here it is reagent injection mode. Samples were maintained at close to the ambient seawater temperature to maintain oxidation of $\mathrm{Fe}(\mathrm{II})$ at in situ rates and $\mathrm{N}_{2}$ gas was used to fill the headspace of the bottles as the sample was removed so as to prevent atmospheric $\mathrm{O}_{2}$ from entering the sample. The detection limit for this technique during this work (all analysis) ranged from 4 to $20 \mathrm{pM}$ and depended mostly on the background chemiluminescence from the luminol reagent. Peak width and shape was used as criteria for the determination of Fe(II) at $<100 \mathrm{pM}$ levels as the presence of a small injection peak can bias peak height based analysis to anomalously higher Fe(II) levels.

Standards for $\mathrm{Fe}(\mathrm{II})$ were run in oxygen deficient water from the core of the OMZ, a key point often overlooked in other studies is that the $\mathrm{Fe}(\mathrm{II})$ analytical signal is dependent on $\mathrm{O}_{2}$ in the sample and in the reagent stream ${ }^{102}$. In the case of samples from a strongly oxygen deficient $\mathrm{OMZ}$, the only $\mathrm{O}_{2}$ supplied is in the reagent stream and thus the size of the sample loop and flow rate are critical as too big a loop, or too slow a flow rate, will lead to a double peak as the reaction is minimized when the ratio of sample to reagent is highest in the mixing zone of the flow cell. Another aspect of this is that values of $\mathrm{Fe}(\mathrm{II})$ in oxygenated waters are likely over estimated due to the increased $\mathrm{O}_{2}$ available for reaction. Standard curves were fitted using a quadratic function due to the nonlinearity of the $\mathrm{Fe}(\mathrm{II})$ response over the wide range of $\mathrm{Fe}(\mathrm{II})$ concentrations encountered $20 \mathrm{pM}$ to $200 \mathrm{nM}$. 
Previously we have applied a further criteria for the detection of $\mathrm{Fe}(\mathrm{II}){ }^{28}$ that discrete samples should be measurable for at least one half-life $\left(t_{1 / 2}\right)$, in the present work the slow oxidation rates in the $\mathrm{OMZ}$ waters meant it was not practical to run the samples over a complete half-life for these samples. An earlier study on Fe(II) in seawater suggested that V(IV) may be an interference to the $\mathrm{Fe}(\mathrm{II})$ method ${ }^{51}$. In the present work we suggest that there there is little efflux of V(IV) from the sediments as while vanadate can be reduced to vanadyl by $\mathrm{H}_{2} \mathrm{~S}$ or organic compounds, the vanadyl ion readily adsorbs to particle surfaces ${ }^{103,104}$ and would not readily diffuse out, though it may be present in resuspended particles. Additionally recent work has indicated that in the oxygen-depleted bottom waters on the Peru margin the removal of dissolved V was not observed 105 suggesting no V(IV) formation.

$\mathrm{H}_{2} \mathrm{O}_{2}$ was measured using a flow injection chemiluminescence (FIA-CL) reagent injection method ${ }^{106}$ as described previously ${ }^{107} . \mathrm{H}_{2} \mathrm{O}_{2}$ standards were made by serial dilution from a primary stock solution (30\% Fluka - Trace Select). The concentration of the primary standard was determined by direct spectrophotometry of the solution $(\varepsilon=$ $\left.40.9 \mathrm{~mol} \mathrm{~L}^{-1} \mathrm{~cm}^{-1},{ }^{108}\right)$. Secondary standards were analysed with a spectrophotometric method using $\mathrm{Cu}(\mathrm{II})$ and 2,9-dimethyl-1,10-phenanthroline ${ }^{109}$. Seawater samples were measured directly by FIA-CL. Sample concentrations were corrected daily for the reagent blank ${ }^{106}$, which was typically less than $0.2 \mathrm{nM}$. We note that another recent work on $\mathrm{H}_{2} \mathrm{O}_{2}$ in seawater ${ }^{110}$ using this method included catalase as part of their blank measurement, however as noted in the original method ${ }^{106}$ this is prone to a range of artefacts due to catalase's low efficiency at low $\mathrm{H}_{2} \mathrm{O}_{2}$ concentrations and its interference 
with the luminol assay ${ }^{111}$. Samples precision was $2-3 \%$ through the concentration range 1-100 $\mathrm{nM}$, the detection limit $(3 \sigma)$ was typically $0.6 \mathrm{nmol} \mathrm{L}^{-1}$.

As mentioned above $\mathrm{O}_{2}$ concentrations in the sample influence the sensitivity of the $\mathrm{Fe}$ (II) measurements ${ }^{102}$, but they don't appear to interfere with $\mathrm{H}_{2} \mathrm{O}_{2}$ analysis ${ }^{106}$. In the original method for the $\mathrm{H}_{2} \mathrm{O}_{2}$ analysis it was recommended to allow samples for $\mathrm{H}_{2} \mathrm{O}_{2}$ with $\mathrm{Fe}(\mathrm{II})$ in them to set for an hour before analysis to allow the Fe(II) to oxidize. However in $\mathrm{OMZ}$ waters we chose to sample both the $\mathrm{Fe}(\mathrm{II})$ and $\mathrm{H}_{2} \mathrm{O}_{2}$ simultaneously, as if there is $\mathrm{O}_{2}$ and $\mathrm{Fe}(\mathrm{II})$ in the sample you will generate $\mathrm{H}_{2} \mathrm{O}_{2}$ as the $\mathrm{Fe}(\mathrm{II})$ oxidises, alternatively if the sample is anoxic then the oxidation of the Fe(II) will be very slow (e.g. hours to days) if the bottle is sufficiently gas tight, thus there is the potential to oxidize the initial $\mathrm{H}_{2} \mathrm{O}_{2}$ present in the sample. Our initial shipboard work indicated that the timescale of oxidation was significantly longer than a few hours and that the potential for $\mathrm{O}_{2}$ permeation into the bottles was increased, leading to increased $\mathrm{H}_{2} \mathrm{O}_{2}$ concentrations post sampling. We have found that high concentrations of $\mathrm{H}_{2} \mathrm{O}_{2}(20 \mathrm{nM}$ or more) can cause a small apparent Fe(II) signal (pM level) but this may be related to reactions at the analysis $\mathrm{pH}$ between $\mathrm{HO}_{2}{ }^{-}$and $\mathrm{Fe}(\mathrm{III})$ in the sample to generate $\mathrm{O}_{2}{ }^{-}$and thus unavoidable as the signal will be dependent on the concentration of dissolved and colloidal iron present in the sample. Lastly other potential interferences for both methods that are possible, but difficult to avoid with unfiltered samples, are $\mathrm{O}_{2}^{-}$production by $\mathrm{O}_{2}$ sensitive bacteria from the $\mathrm{OMZ}$ and/or bioluminescence. 


\section{Results and Discussions}

\subsection{Hydrography}

The location of the stations sampled during the M77-1 expedition are shown in Figure 1 along with the locations of sampling sites from other studies on $\mathrm{Fe}(\mathrm{II})$ in the Peruvian OMZ 53,65. The main hydrographic feature along this part of the Peruvian EBUS is the strong upwelling that occurs year round, which supports some of the highest primary productivity on the globe ${ }^{112}$. The Peruvian OMZ is created and maintained by a high demand for oxygen in the waters underlying the upwelling zone and weak supply of oxygenated waters ${ }^{113}$. The upwelled waters of the $\mathrm{OMZ}$ are sourced from nutrient rich equatorial subsurface water (ESSW) transported by the Peru Chile Undercurrent (PCUC), a poleward flowing current ${ }^{114}$ found at approximately $150 \mathrm{~m}$ depth $10^{\circ}$ and $15^{\circ} \mathrm{S}$ on the Peruvian shelf. Highest chlorophyll concentrations are found in the spring and summer, out of phase with the winter upwelling maximum ${ }^{115}$. Our expedition took place in the austral spring and Figure 2 illustrates the increase in ocean productivity over the shelf immediately preceding and during our work at sea. Long term trends (1996-2011) in the $\mathrm{OMZ}$ and nutrients at a monthly time series station off the coast of Callao (Figure 1) reveal a system responding to variability on seasonal to interannual timescales.

\subsection{Distribution of dissolved Oxygen $\left(\mathrm{O}_{2}\right)$ and Hydrogen Peroxide $\left(\mathrm{H}_{2} \mathrm{O}_{2}\right)$}

\subsection{1 $\mathrm{O}_{2}$ distribution}

The distribution of dissolved oxygen at 3 selected stations are shown in Figures 35 and in the SI (Figures S1-S4). Briefly the surface waters and AML were well oxygenated but $\mathrm{O}_{2}$ rapidly decreased below that to concentrations below $20 \mu \mathrm{M}$. It should 
be noted the Seabird SBE43 polarographic membrane oxygen sensor employed on the CTD in this study, can't resolve $\mathrm{O}_{2}$ concentrations below about 1-2 $\mu \mathrm{M}{ }^{116}$. Recent studies using the STOX electrode ${ }^{116}$ have indicated that there is less than $2 \mathrm{nM} \mathrm{O}_{2}$ in the core of the Peruvian OMZ ${ }^{117}$. $\mathrm{O}_{2}$ concentrations increased below $400 \mathrm{~m}$ at the deeper stations occupied during M77-1 (Figure S6).

\subsection{2 $\mathrm{H}_{2} \mathrm{O}_{2}$ in the $\mathrm{OMZ}$}

$\mathrm{H}_{2} \mathrm{O}_{2}$ concentrations for 3 stations are shown in Figures 3-5 and the data can also be found in the SI. $\mathrm{H}_{2} \mathrm{O}_{2}$ concentrations were elevated as expected in the euphotic zone, presumably due to photochemical processes ${ }^{118}$ an decreased rapidly to very low levels, but still detectable, in the core of the OMZ. $\mathrm{H}_{2} \mathrm{O}_{2}$ concentrations increased again at most stations near the sediment-water interface. There have only been a few other studies on $\mathrm{H}_{2} \mathrm{O}_{2}$ in the Peruvian OMZ, and our results are broadly consistent with them for the euphotic zone, though the earliest study by Zika et al. ${ }^{119}$ could not detect $\mathrm{H}_{2} \mathrm{O}_{2}$ below 5 $\mathrm{nM}$ due to the method employed at the time. The most recent study ${ }^{110}$ only included two stations from the Peru OMZ and reported much higher $\mathrm{H}_{2} \mathrm{O}_{2}$ concentrations $(10 \mathrm{nM})$ than we observed (0.3-2 nM) in the core of the OMZ and they suggested the high values they observed was due to the presence of nM Fe(II). The methodologies used in our study and theirs are very similar, though they report taking their samples after those drawn for $\mathrm{O}_{2}$ and that they collected their samples directly from the spigot on the Niskin (to avoid the possible effects of light), this differs from our work were we sampled first and via a sampling tube as for low $\mathrm{O}_{2}$ measurements to eliminate the introduction of bubbles to the sample. 
$\mathrm{O}_{2}$ is an obligatory precursor for $\mathrm{H}_{2} \mathrm{O}_{2}$ for all known routes of formation and thus it seems somewhat puzzling at first that $\mathrm{H}_{2} \mathrm{O}_{2}$ could exist where there is effectively no $\mathrm{O}_{2}$. However, $\mathrm{H}_{2} \mathrm{O}_{2}$ could be formed at oxic/anoxic boundaries and migrate into anoxic environments, one such route might be from sinking particles where $\mathrm{O}_{2}$ is consumed leading to anoxic microenvironments and a flux of $\mathrm{H}_{2} \mathrm{O}_{2}$ from the sinking particle ${ }^{120,121}$. Further to this a respiratory enzyme in the facultative anaerobe Escherichia coli, cytochrome c peroxidase, was recently found to use $\mathrm{H}_{2} \mathrm{O}_{2}$ as a terminal electron acceptor 122 and was only expressed when $\mathrm{H}_{2} \mathrm{O}_{2}$ is present and molecular oxygen is absent suggesting an unappreciated niche for microbes utilizing this enzyme and substrate.

\subsection{Distribution and fluxes of Fe(II) in the OMZ water column}

\subsubsection{Distribution of $\mathrm{Fe}(\mathrm{II})$}

Significant concentrations of Fe(II) were observed in the water column of the Peruvian shelf during both the M77-1. Examples profile are shown from stations 532 (Figure 3), 599 (Figure 4) and 618 (Figure 5). At this site dissolved oxygen was below 2 $\mu \mathrm{M}$ from $20 \mathrm{~m}$, just below the mixed layer, all the way to the bottom. There was no evidence for any sulfide formation at this time, though a later expedition in the same region would detect sulfide and enhanced benthic Fe fluxes ${ }^{123}$. Fe(II) was detectable at all stations throughout the water column with highest concentrations in the BBL which decreased with proximity from the sediments consistent with a benthic source of $\mathrm{Fe}(\mathrm{II})$. In $\mathrm{OMZ}$ waters, the combination of low $\mathrm{O}_{2}$ and $\mathrm{H}_{2} \mathrm{O}_{2}$, a low $\mathrm{pH}(7.6-7.8)$ results in a dramatic extension of the half-life for Fe(II) in seawater compared to that in warm well oxygenated surface waters. 
Our findings are consistent with earlier work by Hong and Kester on the Peruvian shelf (Figure 1) which also found high concentrations of Fe(II) on the inner shelf close to the sediments ${ }^{65}$, however in that study Fe(II) was measured spectrophotometrically using Ferrozine resulting in a much higher detection limit and many of the features seen in our new data set were not observable. Hong and Kester found Fe(II) and nitrite together suggesting a common source from the sediments and this was also observed by us at station 532 (Figure 3).

High concentrations of iron in Peruvian shelf waters were also observed by Bruland and coworkers ${ }^{59}$ though they did not measure Fe(II) specifically. More recent work by Vedamati et al. ${ }^{53}$ off the shelf but in OMZ waters found Fe(II) maxima coincident with the secondary nitrite maxima (SNM), as has been observed in the Eastern Tropical North Pacific ${ }^{51}$ and the Indian Ocean ${ }^{52}$. This feature is also present in our data at station 532 (unfortunately for the other stations we don't have nitrite data). Chever et al. ${ }^{66}$ also found significant concentration of Fe(II) to the north of our study site.

\subsubsection{Modelling of Fe(II) profiles and estimation of Fluxes}

For many of the stations sampled we could apply a simple 1 layer 1D water column model (see the description above) (Figure 3 and 4). While at other stations the Fe(II) distribution was clearly marked by the presence of a well mixed BBL (Figure 5) which required the use of a 2 layer model. Fitting of the profiles was performed in Matlab $^{\mathrm{TM}}$ using the lsqcurvefit function with the error of the fit estimated using the Jacobian matrix. 
During M77-1, a suite of cores were taken along the same transect as the CTD sampling for which $\mathrm{Fe}(\mathrm{II})$ fluxes were estimated from pore water gradients ${ }^{100}$. In the present work we use those flux estimates to derive oxidation rates using our model. Alternatively we could have calculated the $K_{Z}$ from relationships to the buoyancy gradient for BBLs ${ }^{96}$ and then fitted the equations for $\mathrm{C}_{0}$ and $\lambda$ only to estimate the flux $\mathrm{J}$ (equation 6).

The results from our model simulations are summarized in Table 2. Oxidation rate estimates ranged from $6.7 \times 10^{-8} \mathrm{~s}^{-1}$ to $\sim 9.9 \times 10^{-7} \mathrm{~s}^{-1}$, this is equivalent to a range of halflife values from $\sim 200$ hours to $\sim 2900$ hours ( 8 to 120 days). Our estimates for $K_{Z}$ range from 2.3 to $28.4 \mathrm{~cm}^{2} \mathrm{~s}^{-1}$ for the BBL. These values are reasonably consistent with other measurements from other regions for the BML and BBL though data is sparse ${ }^{31}$.

Cross shelf transport in the Peruvian margin via meso-scale eddies has been identified as a key process in this region ${ }^{60}$. Thus eddies that interacted with the shelf could potentially transport some Fe(II) out across the shelf before it was oxidized and this may represent an important mechanism in the development of INLs ${ }^{67}$ in this region and the supply of Fe to the offshore nutrient rich waters. Alternatively recent $2 \mathrm{D}$ modelling work on EBUS regions has indicated that shelf slope and weak stratification can concentrate onshore transport in the BBL ${ }^{124}$ which could help to supply iron to the upwelled waters. Quantifying the cross-shelf and along shore transport of Fe should therefore be a major goal of future work.

\subsubsection{Oxidation of $\mathrm{Fe}(\mathrm{II})$ in OMZ waters}

\subsubsection{Oxidation kinetics under low $\mathrm{O}_{2}$ conditions}


Comparing our estimates (Table 2) of the in situ Fe(II) half life with those estimated from laboratory studies (Table 1) relies on assuming that these rates scalar according to the rate laws, which may not necessarily hold when going from $\mathrm{mM}$ to $\mathrm{nM}$ concentrations. There is also the question of non-stoichiometry reactions occurring at lower concentrations as other reactions become more important, as seen for $\mathrm{Fe}(\mathrm{II})$ oxidation at low $\mathrm{O}_{2}$ levels, where $\mathrm{H}_{2} \mathrm{O}_{2}$ can become the major oxidant ${ }^{84}$. Our data does suggest however that $\mathrm{O}_{2}$ is not the major oxidant for $\mathrm{Fe}(\mathrm{II})$ in the core of the OMZ, as if using the upper bound of $2 \mathrm{nM} \mathrm{O}_{2}$ given by Revsbech et al. ${ }^{116}$ this would results in an apparent rate of $\sim 5 \times 10^{-10} \mathrm{~s}^{-1}$ much slower than what we estimate using our modelling approach.

At these very slow oxidation rates, there is sufficient time for the inorganic Fe(II) diffusing from the sediments to become complexed or adsorbed to particulate matter, thus changing its oxidation rate ${ }^{28}$. In many instances it may already be organically complexed when it leaves the sediments. It is however still labile as it reacts in the time frame of our analytical method, while for example the strong complex formed between Fe(II) and Ferrozine does not. Heterogeneous oxidation of $\mathrm{Fe}(\mathrm{II})$ on particles is more rapid at ambient $\mathrm{O}_{2}$ concentrations though the few studies that have been made at low $\mathrm{O}_{2}$ levels indicate that there is less of an enhancement on the oxidation rate by particles ${ }^{125,126}$. Although there is now data available on the mineralogy and solid phase speciation of particles in the Peruvian OMZ ${ }^{127}$ we don't have a good indication of how much Fe(II) is adsorbed on them to be able to assess how this might impact the heterogeneous rates of oxidation. 
Based on the analysis of the rate data in Table $1, \mathrm{H}_{2} \mathrm{O}_{2}$ is likely then to be the key oxidant for $\mathrm{Fe}(\mathrm{II})$ but our water column data also strongly suggests that $\mathrm{H}_{2} \mathrm{O}_{2}$ is not present in excess of $\mathrm{Fe}(\mathrm{II})$ often and is thus not capable of completely oxidizing all the $\mathrm{Fe}(\mathrm{II})$ coming out of the sediments, so another oxidant more abundant is required.

\subsubsection{Abiotic and biotic Nitrate/Nitrite reduction - Fe(II) oxidation}

Nitrate and Nitrite in OMZ waters clearly fulfil the condition of being an oxidant in excess that could remove Fe(II) from the water column. If we start by examining the abiotic rates from Table 1 we can see that it is unlikely that $\mathrm{NO}_{3}{ }^{-}$is the oxidant, though $\mathrm{NO}_{2}^{-}$may be important in the secondary nitrite maximum. It is also thought unlikely at this stage that $\mathrm{Cu}$ catalyses the $\mathrm{NO}_{2}^{-}$reaction ${ }^{88}$ under seawater conditions as $\mathrm{Cu}$ is strongly organically complexed in these waters ${ }^{128}$.

So are the biotic reactions as has recent studies have suggested that NDFO is the most likely mechanism for the oxidation of Fe(II) in the Peru OMZ? ${ }^{127,}{ }^{129}$. Microbial genomics studies indicate that a range of taxa can oxidize Fe(II) ${ }^{130}$, most notably the Alphaproteobacteria (phototrophic iron-oxidizing), Betaproteobacteria (neutrophilic aerobic and nitrate-dependent), Gammaproteobacteria (mostly acidophilic) and Zetaproteobacteria. For the anoxic bottom waters on the Peruvian shelf, the current information would suggest that Fe(II) oxidation would be likely carried out by Betaproteobacteria and/or Zetaproteobacteria. Cellular oxidation rates for Fe(II) by Zetaproteobacteria are available from a recent study by ${ }^{131}$ and this indicates that oxidizing 1-10 nM of Fe(II) over a time frame of 200 to 2900 hours (see above) would require only $\sim 50$ to 7500 cells $\mathrm{L}^{-1}$ which would only be a small fraction of the 
metabolically active cells present in the water column. As there is no information on the temperature dependence of these organisms it is likely at colder temperatures the rates may be slower than reported here. However it does appear that NDFO bacteria are the most likely controls on Fe(II) in the Peru OMZ, if this is the case and the bacteria were uniformly distributed in the BBL and/or core of the $\mathrm{OMZ}$ this would then be some support for our assumption in equation 2 that the rate of Fe(II) oxidation was constant (e.g. $\lambda=k_{N D F O}[$ cell] $)$, this however awaits quantification of Fe(II) oxidizing bacteria and measurement of these rates under ambient conditions.

One key aspect of Fe cycling that still remains unclear at present however is the kinetics of formation and oxidation of Fe(II) at the SNM (Figure 3) as the presence of NDFO bacteria and/or abiotic $\mathrm{NO}_{2}{ }^{-}$oxidation helps explain the $\mathrm{Fe}(\mathrm{II})$ loss terms, but for this feature to form it requires a faster reductive process to be occurring so that significant concentrations of $\mathrm{Fe}(\mathrm{II})$ can be built up. This is an interesting puzzle that requires further investigation.

\subsection{Residence time of Fe(II) in the Peru OMZ}

Previously Scholz et al. ${ }^{129}$ estimated the residence time of Fe in the Peruvian OMZ to be $16-18 \mathrm{~h}$ based solely on Fe(II) fluxes and the total water column inventory for dissolved iron, our data for the same region indicate a longer residence time for Fe(II) based of 200 to 2900 hours. In the case of Scholz et al. they made the assumption the dissolved iron loss term was all due to NDFO. A further difference between our estimate and theirs is also in the inventories, as we only considered Fe(II) and their estimate is made using the total dissolved iron pool (Fe(II) and Fe(III)). Our model only examines 
Fe(II) oxidation losses, while their loss term would be scavenging of dissolved Fe(III) by particulate phases which is likely to be the main driver of the short residence time for dissolved iron in these waters. This is analogous to aerosol deposition in the upper ocean under the Saharan dust plume, where dissolved iron has a significantly longer residence time than total iron ${ }^{132}$.

\section{Conclusions and Future work}

We have shown that combined measurements of $\mathrm{Fe}(\mathrm{II})$ and $\mathrm{H}_{2} \mathrm{O}_{2}$ provide valuable information on redox processes and mixing in the BBL of the Peruvian $\mathrm{OMZ}$ and can be combined with benthic flux estimates to improve modelling of iron fluxes to EBUS regions. Our data also indicate that $\mathrm{H}_{2} \mathrm{O}_{2}$ may be an important transient species in $\mathrm{OMZ}$, but it is unlikely to be the controlling oxidant for $\mathrm{Fe}(\mathrm{II})$ as it appears at present that NDFO bacteria are capable of this. Overall it is expected that this new approach to iron redox processes will help to significantly improve our understanding of redox cycling in the ocean and on mixing processes at ocean boundaries.

\section{Associated Content:}

The supporting information is available free of charge on the ACS Publications website at DOI: $10.1021 /$ acsearthspac-chem.xxxxxxx

Location of stations sampled during M77-1 for Fe(II) (Table S1); $\mathrm{Fe}(\mathrm{II})$ and $\mathrm{H}_{2} \mathrm{O}_{2}$ at S532 (Table S2); Fe(II) and $\mathrm{H}_{2} \mathrm{O}_{2}$ at S547 (Table S3); $\mathrm{Fe}(\mathrm{II})$ and $\mathrm{H}_{2} \mathrm{O}_{2}$ at $\mathrm{S} 556$ (Table S4); Vertical profiles for hydrographic and redox parameters at S556 (Figure S1); Fe(II) and $\mathrm{H}_{2} \mathrm{O}_{2}$ at S569 (Table S5); Vertical profiles for hydrographic and redox parameters at 
S569 (Figure S2); Fe(II) and $\mathrm{H}_{2} \mathrm{O}_{2}$ at S575 (Table S6); Vertical profiles for hydrographic and redox parameters at S575 (Figure S3); Fe(II) and $\mathrm{H}_{2} \mathrm{O}_{2}$ at S596 (Table S7); Fe(II) and $\mathrm{H}_{2} \mathrm{O}_{2}$ at 5599 (Table S8); $\mathrm{Fe}(\mathrm{II})$ and $\mathrm{H}_{2} \mathrm{O}_{2}$ at $\mathrm{S} 609$ (Table S9); Vertical profiles for hydrographic and redox parameters at $\mathrm{S} 609$ (Figure $\mathrm{S} 4$ ); $\mathrm{Fe}(\mathrm{II})$ and $\mathrm{H}_{2} \mathrm{O}_{2}$ at $\mathrm{S} 618$ (Table $\mathrm{S} 10$ ); $\mathrm{O}_{2}$ concentrations (as measured by a SBE-43 sensor) along for the transect along $11^{\circ} \mathrm{S}$ during M77-1 (Figure S5); Fe(II) oxidation half-life comparison (Figure S6) (PDF)

\section{Acknowledgements:}

We kindly thank the government of Peru for allowing us access to their territorial waters and to the officers and crew of RV Meteor for their help and cooperation during the research expedition M77-1 described in this work. Special thanks are also due to our colleagues at GEOMAR for their support of our shipboard and shore-based laboratory work. We gratefully acknowledge the authorities in Peru for their kind permission to work in their territorial waters. This work is a contribution of the Sonderforschungsbereich 754 "Climate - Biogeochemistry Interactions in the Tropical Ocean" (www.sfb754.de). Financial support for this work was provided by the Deutsche Forschungsgemeinschaft (DFG) via grants to PLC (CR145/15-1 and SFB754 B5). Aspects of this work were also supported by SOPRAN, a BMBF Verbundsprojekt (FKZ 03F0462A and 03F0611A) which forms part of the German contribution to SOLAS. PLC acknowledges that this publication has emanated from research supported in part by a research grant from Science Foundation Ireland (SFI) under Grant Number 13/RC/2092 and co-funded under the European Regional Development Fund and by iCRAG industry partners. This work is also a contribution to SCOR working group 151: Iron Model Intercomparison Project (FeMIP). 


\section{References}

1. Tagliabue, A.; Völker, C., Towards accounting for dissolved iron speciation in global ocean models. Biogeosciences 2011, 8 (10), 3025-3039.

2. Tagliabue, A.; Bowie, A. R.; Boyd, P. W.; Buck, K. N.; Johnson, K. S.; Saito, M. A., The integral role of iron in ocean biogeochemistry. Nature 2017, 543 (7643), 5159.

3. Tagliabue, A.; Aumont, O.; DeAth, R.; Dunne, J. P.; Dutkiewicz, S.; Galbraith, E.; Misumi, K.; Moore, J. K.; Ridgwell, A.; Sherman, E.; Stock, C.; Vichi, M.; Völker, C.; Yool, A., How well do global ocean biogeochemistry models simulate dissolved iron distributions? Global Biogeochemical Cvcles 2016, 30 (2), 149-174.

4. Wallace, D. W. R.; Beining, P.; Putzka, A., Carbon-Tetrachloride And Chlorofluorocarbons In The South-Atlantic Ocean, 19-Degrees-S. J. Geophys. Res.Oceans 1994, 99 (C4), 7803-7819.

5. Whitworth, T.; Nowlin, W. D.; Pillsbury, R. D.; Moore, M. I.; Weiss, R. F., Observations Of The Antarctic Circumpolar Current And Deep Boundary Current In The Southwest Atlantic. J. Geophvs. Res.-Oceans 1991, 96 (C8), 15105-15118.

6. Waugh, D. W.; Hall, T. M.; Haine, T. W. N., Relationships among tracer ages. $L$ Geophvs. Res. 2003, 108 (C5), 3138.

7. Bluhm, K.; Croot, P. L.; Huhn, O.; Rohardt, G.; Lochte, K., Distribution of iodide and iodate in the Atlantic sector of the southern ocean during austral summer. Deep Sea Research Part UL: Topical Studies in Oceanogranhv 2011, 58 (25-26), 27332748.

8. Croot, P. L.; Bluhm, K.; Schlosser, C.; Streu, P.; Breitbarth, E.; Frew, R.; Van Ardelan, M., Regeneration of Fe(II) during EIFeX and SOFeX. Geophysical Research Letters 2008, 35 (19), L19606,doi:10.1029/2008GL035063.

9. Hou, X. L.; Dahlgaard, H.; Nielsen, S. P., Chemical speciation analysis of I-129 in seawater and a preliminary investigation to use it as a tracer for geochemical cycle study of stable iodine. Marine Chemistrv 2001, 74 (2-3), 145-155.

10. Paulmier, A.; Ruiz-Pino, D., Oxygen minimum zones (OMZs) in the modern ocean. Progress In Oceanogranhy 2009, 80 (3-4), 113-128.

11. Stramma, L.; Johnson, G. C.; Sprintall, J.; Mohrholz, V., Expanding OxygenMinimum Zones in the Tropical Oceans. Science 2008, 320 (5876), 655-658.

12. Rue, E. L.; Smith, G. J.; Cutter, G. A.; Bruland, K. W., The response of trace element redox couples to suboxic conditions in the water column. Deep-Sea Research I 1997, 44, 113-134.

13. Cutter, G. A.; Moffett, J. W.; Nielsdóttir, M. C.; Sanial, V., Multiple oxidation state trace elements in suboxic waters off Peru: In situ redox processes and advective/diffusive horizontal transport. Marine Chemistrv 2018, 201, 77-89.

14. Bryce, C.; Blackwell, N.; Schmidt, C.; Otte, J.; Huang, Y.-M.; Kleindienst, S.; Tomaszewski, E.; Schad, M.; Warter, V.; Peng, C.; Byrne, J. M.; Kappler, A., Microbial anaerobic Fe(II) oxidation - Ecology. mechanisms and environmental implications. 2018, 20 (10), 3462-3483.

15. Straub, K. L.; Benz, M.; Schink, B.; Widdel, F., Anaerobic, nitrate-dependent microbial oxidation of ferrous iron. Anplied and Environmental Microbiologv 1996, 62 (4), 1458-1460. 
16. Yang, W. H.; Weber, K. A.; Silver, W. L., Nitrogen loss from soil through anaerobic ammonium oxidation coupled to iron reduction. Nature Geosci 2012, 5 (8), 538-541.

17. Price, A.; Pearson, V. K.; Schwenzer, S. P.; Miot, J.; Olsson-Francis, K., Nitrate-Dependent Iron Oxidation: A Potential Mars Metabolism. Erontiers in Microbiology 2018, 9 (513), 10.3389/fmicb.2018.00513.

18. Melton, E. D.; Swanner, E. D.; Behrens, S.; Schmidt, C.; Kappler, A., The interplay of microbially mediated and abiotic reactions in the biogeochemical Fe cycle. Nat Rev Micro 2014, 12 (12), 797-808.

19. Denman, K. L.; Gargett, A. E., Time and space scales of vertical mixing and advection of phytoplankton in the upper ocean. Limnol. Oceanogr. 1983, 28, 801-815.

20. MacIntyre, S., Turbulent mixing and resource supply to phytoplankton. In Physical Processes in Lakes and Oceans, Imberger, J., Ed. AGU: 1998; pp 539-567.

21. Brainerd, K. E.; Gregg, M. C., Surface mixed and mixing layer depths. Deen Sea Research Part I: Oceanographic Research Paners 1995, 42, 1521-1543.

22. Thorpe, S. A., Turbulence and mixing in a Scottish Loch. Philosophical Transactions of the Roval Societv London Series A 1977, 286, 125-181.

23. Roget, E.; Lozovatsky, I.; Sanchez, X.; Figueroa, M., Microstructure measurements in natural waters: Methodology and applications. Progress In Oceanogranhv 2006, 70 (2-4), 126-148.

24. Cisewski, B.; Strass, V. H.; Prandke, H., Upper-ocean vertical mixing in the Antarctic Polar Front Zone. Deen Sea Research Part U. Tonical Studies in Oceanographv 2005, 52 (9-10), 1087-1108.

25. Stevens, C.; Ward, B.; Law, C.; Walkington, M., Surface layer mixing during the SAGE ocean fertilization experiment. Deep Sea Research Part II: Topical Studies in Oceanogranhv 2011, 58 (6), 776-785.

26. Schafstall, J.; Dengler, M.; Brandt, P.; Bange, H., Tidal-induced mixing and diapycnal nutrient fluxes in the Mauritanian upwelling region. L.Geophvs. Res. 2010, 115 (C10), C10014.

27. Law, C. S.; Martin, A. P.; Liddicoat, M. I.; Watson, A. J.; Richards, K. J.; Woodward, E. M. S., A Lagrangian SF6 tracer study of an anticyclonic eddy in the North Atlantic: patch evolution, vertical mixing and nutrient supply to the mixed layer. DeenSea Res. Part II-Ton. Stud. Oceanogr. 2001, 48 (4-5), 705-724.

28. Croot, P. L.; Frew, R. D.; Hunter, K. A.; Sander, S.; Ellwood, M. J.; Abraham, E. R.; Law, C. S.; Smith, M. J.; Boyd, P. W., The effects of physical forcing on iron chemistry and speciation during the FeCycle experiment in the South West Pacific. Journal of Geophysical Research - Oceans 2007, 112, C06015, doi:10.1029/2006JC003748.

29. Cisewski, B.; Strass, V. H.; Losch, M.; Prandke, H., Mixed layer analysis of a mesoscale eddy in the Antarctic Polar Front Zone. Journal Of Geophysical ResearchOceans And Atmospheres 2008, 113 (C5), C05017, doi:10.1029/2007JC004372. 30. Armi, L.; D'Asaro, E., Flow Structures of the Benthic Ocean. L.Geophvs.Res. 1980, 85 (C1), 469-484.

31. Holtappels, M.; Lorke, A., Estimating turbulent diffusion in a benthic boundary layer. Limnologv And Oceanographv-Methods 2011, 9, 29-41. 
32. Dade, B. D.; Hogg, A.; Boudreau, B. P., Physics of flow above the sedimentwater interface. In The benthic boundary layer: transport processes and biogeochemistry, Boudreau, B. P.; Jorgensen, B. B., Eds. Oxford University Press: 2001; pp 4-43.

33. Beaulieu, S.; Baldwin, R., Temporal variability in currents and the benthic boundary layer at an abyssal station off central California. Deep Sea Research Part II: Tonical Studies in Oceanographv 1998, 45 (4-5), 587-615.

34. McCave, I. N., Local and global aspects of the bottom nepheloid layers in the world ocean. Netherlands Journal of Sea Research 1986, 20 (2-3), 167-181.

35. Inthorn, M.; Mohrholz, V.; Zabel, M., Nepheloid layer distribution in the Benguela upwelling area offshore Namibia. Deen Sea Research Part I: Oceanographic Research Papers 2006, 53 (8), 1423-1438.

36. Holtappels, M.; Kuypers, M. M. M.; Schluter, M.; Bruchert, V., Measurement and interpretation of solute concentration gradients in the benthic boundary layer. Limnologv And Oceanographv-Methods 2011, 9, 1-13.

37. Price, J. F.; Weller, R. A.; Pinkel, R., Diurnal cycling: Observations and Models of the Upper Ocean Response to Diurnal Heating, Cooling, and Wind Mixing. Journal of Geophvsical Research 1986, 91 (C7), 8411-8427.

38. Umlauf, L.; Burchard, H., Second-order turbulence closure models for geophysical boundary layers. A review of recent work. Continental Shelf Research 2005, 25 (7), 795-827.

39. Weber, L.; Völker, C.; Oschlies, A.; Burchard, H., Iron profiles and speciation of the upper water column at the Bermuda Atlantic Time-series Study site: a model based sensitivity study. Biogeosciences 2007, 4 (4), 689-706.

40. Croot, P. L.; Laan, P.; Nishioka, J.; Strass, V.; Cisewski, B.; Boye, M.; Timmermans, K.; Bellerby, R.; Goldson, L.; de Baar, H. J. W., Spatial and Temporal distribution of $\mathrm{Fe}(\mathrm{II})$ and $\mathrm{H}_{2} \mathrm{O}_{2}$ during EISENEX, an open ocean mesoscale iron enrichment. Marine Chemistrv 2005, 95, 65-88.

41. Millero, F. J.; Sotolongo, S., The oxidation of Fe(II) with $\mathrm{H}_{2} \mathrm{O}_{2}$ in seawater. Geochimica et Cosmochimica Acta 1989, 53, 1867-1873.

42. Millero, F. J.; Sotolongo, S.; Izaguirre, M., The oxidation kinetics of Fe(II) in seawater. Geochimica et Cosmochimica Acta 1987, 51, 793-801.

43. Croot, P. L.; Hunter, K. A., Labile forms of iron in coastal seawater: Otago Harbour, New Zealand. Marine Ereshwater Research 2000, 51, 193-203.

44. Croot, P. L.; Johansson, M., Determination of iron speciation by cathodic stripping voltammetry in seawater using the competing ligand 2-(2-Thiazolylazo)-pcresol (TAC). Electroanalvsis 2000, 12(8), 565-576.

45. Gledhill, M.; Buck, K. N., The organic complexation of iron in the marine environment: A review. Erontiers in Microbiology 2012, 3, 10.3389/fmicb.2012.00069.

46. Kuma, K.; Nishioka, J.; Matsunaga, K., Controls on iron(III) hydroxide solubility in seawater: The influence of $\mathrm{pH}$ and natural organic chelators. Limnol. Oceanogr. 1996, 41, 396-407.

47. Rijkenberg, M. J. A.; Fischer, A. C.; Kroon, J. J.; Gerringa, L. J. A.; Timmermans, K. R.; Wolterbeek, H. T.; de Baar, H. J. W., The influence of UV irradiation on the photoreduction of iron in the Southern Ocean. Marine Chemistrv 2005, 93, 119-129. 
48. Wells, M. L.; Mayer, L. M.; Donard, O. F. X.; de Souza Sierra, M. M.; Ackelson, S. G., The photolysis of colloidal iron in the oceans. Nature 1991, 353, 248250 .

49. Johnson, K. S.; Coale, K. H.; Elrod, V. A.; Tindale, N. W., Iron photochemistry in seawater from the equatorial Pacific. Marine Chemistry 1994, 46, 319-334. 50. Kuma, K.; Nakabayashi, S.; Suzuki, Y.; Kudo, I.; Matsunaga, K., Photoreduction of $\mathrm{Fe}(\mathrm{III})$ by dissolved organic substances and existence of $\mathrm{Fe}(\mathrm{II})$ in seawater during spring blooms. Marine Chemistrv 1992, 37, 15-27.

51. Hopkinson, B. M.; Barbeau, K. A., Organic and redox speciation of iron in the eastern tropical North Pacific suboxic zone. Marine Chemistrv 2007, 106, 2-17. 52. Moffett, J. W.; Goeffert, T. J.; Naqvi, S. W. A., Reduced iron associated with secondary nitrite maxima in the Arabian Sea. Deep-Sea Research Part I-Oceanographic Research Papers 2007, 54 (8), 1341-1349.

53. Vedamati, J.; Goepfert, T.; Moffett, J. W., Iron speciation in the eastern tropical South Pacific oxygen minimum zone off Peru. Limnol. Oceanogr. 2014, 59 (6), 19451957.

54. Elrod, V. A.; Berelson, W. M.; Coale, K. H.; Johnson, K. S., The flux of iron from continental shelf sediments: A missing source for global budgets. Geophvsical Research Letters 2004, 31, L12307, doi:10.1029/2004GL020216.

55. Croot, P. L.; Hunter, K. A., Trace metal distributions across the continental shelf near Otago Peninsula, New Zealand. Marine Chemistru 1998, 62, 185-201.

56. Johnson, K. S.; Chavez, F. P.; Friederich, G. E., Continental-shelf sediment as a primary source of iron for coastal phytoplankton. Nature 1999, 398, 697-700.

57. Johnson, K. S.; Chavez, F. P.; Elrod, V. A.; Fitzwater, S. E.; Pennington, J. T.; Buck, K. R.; Walz, P. M., The annual cycle of iron and the biological response in central California coastal systems. Geophvsical Research Letters 2001, 28, 1247-1250.

58. Bruland, K. W.; Rue, E. L.; Smith, G. J., Iron and macronutrients in California coastal upwelling regimes: Implications for diatom blooms. Limnol. Oceanogr. 2001, 46, 1661-1674.

59. Bruland, K. W.; Rue, E. L.; Smith, G. J.; DiTullio, G. R., Iron, macronutrients and diatom blooms in the Peru upwelling regime: brown and blue waters of Peru. Marine Chemistry 2005, 93 (2-4), 81-103.

60. Chaigneau, A.; Gizolme, A.; Grados, C., Mesoscale eddies off Peru in altimeter records: Identification algorithms and eddy spatio-temporal patterns. Progress In Oceanography 2008, 79 (2-4), 106-119.

61. Chaigneau, A.; Le Texier, M.; Eldin, G.; Grados, C.; Pizarro, O., Vertical structure of mesoscale eddies in the eastern South Pacific Ocean: A composite analysis from altimetry and Argo profiling floats. L.Geophvs. Res. 2011, 116 (C11), C11025. 62. Gruber, N.; Lachkar, Z.; Frenzel, H.; Marchesiello, P.; Munnich, M.; McWilliams, J. C.; Nagai, T.; Plattner, G.-K., Eddy-induced reduction of biological production in eastern boundary upwelling systems. Nature Geosci 2011, 4 (11), 787-792. 63. Bourbonnais, A.; Altabet, M. A.; Charoenpong, C. N.; Larkum, J.; Hu, H.; Bange, H. W.; Stramma, L., N-loss isotope effects in the Peru oxygen minimum zone studied using a mesoscale eddy as a natural tracer experiment. Global Biogeochemical Cycles 2015, 2014GB005001. 
64. Löscher, C. R.; Bourbonnais, A.; Dekaezemacker, J.; Charoenpong, C. N.; Altabet, M. A.; Bange, H. W.; Czeschel, R.; Hoffmann, C.; Schmitz, R., N2 fixation in eddies of the eastern tropical South Pacific Ocean. Biogeosciences 2016, 13 (10), 28892899.

65. Hong, H.; Kester, D. R., Redox state of iron in offshore waters of Peru. Limnol. Oceanogr. 1986, 31, 512-524.

66. Chever, F.; Rouxel, O. J.; Croot, P. L.; Ponzevera, E.; Wuttig, K.; Auro, M., Total dissolvable and dissolved iron isotopes in the water column of the Peru upwelling regime. Geochimica et Cosmochimica Acta 2015, 162 (0), 66-82.

67. Pak, H.; Codispoti, L. A.; Zaneveld, J. R. V., On the intermediate particle maxima associated with oxygen-poor water off western South America. Deep Sea Research Part A. Oceanographic Research Papers 1980, 27 (10), 783-797.

68. Pakhomova, S. V.; Hall, P. O. J.; Kononets, M. Y.; Rozanov, A. G.; Tengberg, A.; Vershinin, A. V., Fluxes of iron and manganese across the sediment water interface under various redox conditions. Marine Chemistrv 2007, 107 (3), 319-331.

69. Klar, J. K.; Homoky, W. B.; Statham, P. J.; Birchill, A. J.; Harris, E. L.; Woodward, E. M. S.; Silburn, B.; Cooper, M. J.; James, R. H.; Connelly, D. P.; Chever, F.; Lichtschlag, A.; Graves, C., Stability of dissolved and soluble Fe(II) in shelf sediment pore waters and release to an oxic water column. Biogeochemistry 2017, 135 (1), 49-67.

70. Homoky, W. B.; Severmann, S.; McManus, J.; Berelson, W. M.; Riedel, T. E.; Statham, P. J.; Mills, R. A., Dissolved oxygen and suspended particles regulate the benthic flux of iron from continental margins. Marine Chemistry 2012, 134-135 (0), 5970 .

71. Gerringa, L. J. A.; Blain, S.; Laan, P.; Sarthou, G.; Veldhuis, M. J. W.; Brussaard, C. P. D.; Viollier, E.; Timmermans, K. R., Fe-binding dissolved organic ligands near the Kerguelen Archipelago in the Southern Ocean (Indian sector). Deen-Sea Res. Part JL-Ton. Stud. Oceanogr. 2008, 55 (5-7), 606-621.

72. Luther III, G. W.; Kostka, J. E.; Church, T. M.; Sulzberger, B.; Stumm, W., Seasonal iron cycling in the salt-marsh sedimentary environment: the importance of ligand complexes with $\mathrm{Fe}$ (II) and $\mathrm{Fe}$ (III) in the dissolution of $\mathrm{Fe}$ (III) minerals and pyrite, respectively. Marine Chemistry 1992, 40, 81-103.

73. Lohan, M. C.; Bruland, K. W., Elevated Fe(II) and dissolved Fe in hypoxic shelf waters off Oregon and Washington: An enhanced source of iron to coastal upwelling regimes. Environmental Science \& Technologv 2008, 42 (17), 6462-6468.

74. Croot, P. L.; Heller, M. I., The importance of kinetics and redox in the biogeochemical cycling of iron in the surface ocean. Frontiers in Microbiology 2012, 3, 10.3389/fmicb.2012.00219.

75. Santana-Casiano, J. M.; Gonzalez-Davila, M.; Millero, F. J., The role of Fe(II) species on the oxidation of $\mathrm{Fe}(\mathrm{II})$ in natural waters in the presence of $\mathrm{O}_{2}$ and $\mathrm{H}_{2} \mathrm{O}_{2}$. Marine Chemistrv 2006, 99 (1-4), 70-82.

76. King, D. W.; Lounsbury, H. A.; Millero, F. J., Rates and Mechanism of Fe(II) Oxidation at Nanomolar Total Iron Concentrations. Environmental Science and Technologv 1995, 29, 818-824.

77. King, D. W., Role of Carbonate Speciation on the Oxidation Rate of Fe(II) in Aquatic Systems. Environmental Science and Technologv 1998, 32, 2997-3003. 
78. Santana-Casiano, J. M.; Gonzalez-Davila, M.; Millero, F. J., Oxidation of Nanomolar Levels of Fe(II) with Oxygen in Natural Waters. Environ. Sci.Technol. 2005, 39 (7), 2073-2079.

79. González-Davila, M.; Santana-Casiano, J. M.; Millero, F. J., Oxidation of iron (II) nanomolar with $\mathrm{H}_{2} \mathrm{O}_{2}$ in seawater. Geochimica et Cosmochimica Acta 2005, 69 (1), 83-93.

80. Croot, P. L.; Hunter, K. A., Determination of Fe(II) and total iron in natural waters with 3-(2-pyridyl)-5,6-diphenyl-1,2,4-triazine (PDT). Analvtica Chimica Acta 2000, 406, 289-302.

81. Croot, P. L.; Laan, P., Continuous shipboard determination of Fe(II) in Polar waters using flow injection analysis with chemiluminescence detection. Analvtica Chimica Acta 2002, 466, 261-273.

82. Sugimori, H.; Kanzaki, Y.; Murakami, T., Relationships between Fe redistribution and $\mathrm{Po} 2$ during mineral dissolution under low $\mathrm{O} 2$ conditions. Geochimica et Cosmochimica Acta 2012, 84 (0), 29-46.

83. Sugimori, H.; Kanzaki, Y.; Yokota, K.; Murakami, T., Nonlinear dependence of the oxidation rate of $\mathrm{Fe}(\mathrm{II})$ on dissolved oxygen under low-O-2 conditions in aqueous solutions. Journal of Mineralogical and Petrological Sciences 2011, 106 (3), 142-152. 84. Kanzaki, Y.; Murakami, T., Rate law of Fe(II) oxidation under low O2 conditions. Geochimica et Cosmochimica Acta 2013, 123 (0), 338-350.

85. Picardal, F., Abiotic and microbial interactions during anaerobic transformations of Fe(II) and NOx. Erontiers in Microbiology 2012, 3, 10.3389/fmicb.2012.00112.

86. Petersen, H. J. S., Reduction of Nitrate by Iron(II). Acta Chemica Scandinavica 1979, 33a, 795-796.

87. Buresh, R. J.; Moraghan, J. T., Chemical Reduction of Nitrate by Ferrous Iron. Journal of Environmental Ouality 1976, 5 (3), 320-325.

88. Ottley, C. J.; Davison, W.; Edmunds, W. M., Chemical catalysis of nitrate reduction by iron (II). Geochimica et Cosmochimica Acta 1997, 61 (9), 1819-1828. 89. Moraghan, J. T.; Buresh, R. J., Chemical Reduction of Nitrite and Nitrous Oxide by Ferrous Iron. Soil Sci.Soc.Am.J. 1976, 41 (1), 47-50.

90. Grabb, K. C.; Buchwald, C.; Hansel, C. M.; Wankel, S. D., A dual nitrite isotopic investigation of chemodenitrification by mineral-associated $\mathrm{Fe}$ (II) and its production of nitrous oxide. Geochimica et Cosmochimica Acta 2017, 196 (Supplement C), 388-402.

91. Klueglein, N.; Kappler, A., Abiotic oxidation of Fe(II) by reactive nitrogen species in cultures of the nitrate-reducing Fe(II) oxidizer Acidovorax sp. BoFeN1 questioning the existence of enzymatic Fe(II) oxidation. Geobiologv 2013, 11 (2), 180190.

92. Jamieson, J.; Prommer, H.; Kaksonen, A. H.; Sun, J.; Siade, A. J.; Yusov, A.; Bostick, B., Identifying and Quantifying the Intermediate Processes during NitrateDependent Iron(II) Oxidation. Environmental Science \& Technologv 2018, 52 (10), 57715781.

93. Chung, Y.-c.; Craig, H., Excess-radon and temperature profiles from the Eastern Equatorial Pacific. Earth and Planetarv Science Letters 1972, 14 (1), 55-64.

94. Smethier, J. W. M., Vertical mixing rates in fjords determined using radon and salinity as tracers. Estuarine. Coastal and Shelf Science 1981, 12 (2), 131-153. 
95. Berelson, W. M.; Hammond, D. E.; Fuller, C., Radon-222 as a tracer for mixing in the water column and benthic exchange in the southern California borderland. Earth and Planetarv Science Letters 1982, 61 (1), 41-54.

96. Sarmiento, J. L.; Feely, H. W.; Moore, W. S.; Bainbridge, A. E.; Broecker, W. $\mathrm{S}$., The relationship between vertical eddy diffusion and buoyancy gradient in the deep sea. Earth and Planetarv Science Letters 1976, 32, 357-370.

97. Broecker, W. S.; Cromwell, J.; Li, Y. H., Rates of vertical eddy diffusion near the ocean floor based on measurements of the distribution of excess 222Rn. Earth and Planetarv Science Letters 1968, 5, 101-105.

98. Peng, T. H.; Takahashi, T.; Broecker, W. S., Surface radon measurements in the North Pacific Ocean station Papa. Journal of Geophvsical Research 1974, 79 (12), 1772 1780.

99. Mosch, T.; Sommer, S.; Dengler, M.; Noffke, A.; Bohlen, L.; Pfannkuche, O.; Liebetrau, V.; Wallmann, K., Factors influencing the distribution of epibenthic megafauna across the Peruvian oxygen minimum zone. Deen Sea Research Part I: Oceanographic Research Paners 2012, 68 (0), 123-135.

100. Noffke, A.; Hensen, C.; Sommer, S.; Scholz, F.; Bohlen, L.; Mosch, T.; Graco, M.; Wallmann, K., Benthic iron and phosphorus fluxes across the Peruvian oxygen minimum zone. Limnol. Oceanogr. 2012, 57 (3), 851-867.

101. Langdon, C. Determination of dissolved oxygen in seawater by winkler titration using the amperometric technique; 2010; pp ICPO Publication Series Number 134. Available online at: http://www.go-ship.org/HydroMan.html.

102. Klopf, L. L.; Nieman, T. A., Effect of Iron(II), Cobalt(II), Copper(II) and Manganese(II) on the Chemiluminescence of Luminol in the Absence of Hydrogen Peroxide. Analvtical Chemistry 1983, 55, 1080-1083.

103. Breit, G. N.; Wanty, R. B., Vanadium accumulation in carbonaceous rocks: A review of geochemical controls during deposition and diagenesis. Chemical Geologv 1991, 91 (2), 83-97.

104. Wehrli, B.; Stumm, W., Vanadyl in natural waters: Adsorption and hydrolysis promote oxygenation. Geochimica et Cosmochimica Acta 1989, 53, 69-77.

105. Ho, P.; Lee, J.-M.; Heller, M. I.; Lam, P. J.; Shiller, A. M., The distribution of dissolved and particulate Mo and V along the U.S. GEOTRACES East Pacific Zonal Transect (GP16): The roles of oxides and biogenic particles in their distributions in the oxygen deficient zone and the hydrothermal plume. Marine Chemistrv 2018, 201, 242255.

106. Yuan, J.; Shiller, A. M., Determination of Subnanomolar Levels of Hydrogen Peroxide in Seawater by Reagent-Injection Chemiluminescence Detection. Analutical Chemistrv 1999, 71, 1975-1980.

107. Croot, P. L.; Streu, P.; Peeken, I.; Lochte, K.; Baker, A. R., Influence of the ITCZ on $\mathrm{H}_{2} \mathrm{O}_{2}$ in near surface waters in the equatorial Atlantic Ocean. Geophysical Research Letters 2004, 31, L23S04, doi:10.1029/2004GL020154.

108. Hwang, H.; Dasgupta, P. K., Thermodynamics of the Hydrogen Peroxide-Water System. Environmental Science and Technologv 1985, 19, 255-258.

109. Kosaka, K.; Yamada, H.; Matsui, S.; Echigo, S.; Shishida, K., Comparison among the methods for hydrogen peroxide measurements to evaluate advanced oxidation 
processes: Application of a spectrophotometric method using copper(II) ion and 2.9 dimethyl-1,10-phenanthroline. Environmental Science \& Technologv 1998, 32 (23), 3821-3824.

110. Hopwood, M. J.; Rapp, I.; Schlosser, C.; Achterberg, E. P., Hydrogen peroxide in deep waters from the Mediterranean Sea, South Atlantic and South Pacific Oceans. Scientific Reports 2017, 7, 43436.

111. Y1ld1z, G.; Demiryürek, A. T., Ferrous iron-induced luminol chemiluminescence: a method for hydroxyl radical study. Journal of Pharmacological and Toxicological Methods 1998, 39 (3), 179-184.

112. Carr, M.-E.; Kearns, E. J., Production regimes in four Eastern Boundary Current systems. Deep Sea Research Part UI: Topical Studies in Oceanographv 2003, 50 (22-26), 3199-3221.

113. Helly, J. J.; Levin, L. A., Global distribution of naturally occurring marine hypoxia on continental margins. Deep-Sea Research 2004, 51, 1159-1168.

114. Huyer, A.; Knoll, M.; Paluszkiewicz, T.; Smith, R. L., The Peru Undercurrent: a study in variability. Deen Sea Research Part A. Oceanogranhic Research Paners 1991, 38, S247-S271.

115. Graco, M. I.; Purca, S.; Dewitte, B.; Castro, C. G.; Morón, O.; Ledesma, J.; Flores, G.; Gutiérrez, D., The OMZ and nutrient features as a signature of interannual and low-frequency variability in the Peruvian upwelling system. Biogeosciences 2017, 14 (20), 4601-4617.

116. Revsbech, N. P.; Larsen, L. H.; Gundersen, J.; Dalsgaard, T.; Ulloa, O.; Thamdrup, B., Determination of ultra-low oxygen concentrations in oxygen minimum zones by the STOX sensor. Limnol. Oceanogr. Methods 2009, 7, 371-381.

117. Thamdrup, B.; Dalsgaard, T.; Revsbech, N. P., Widespread functional anoxia in the oxygen minimum zone of the Eastern South Pacific. Deep Sea Research PartI: Oceanogranhic Research Paners 2012, 65 (0), 36-45.

118. Steigenberger, S.; Croot, P. L., Identifying the processes controlling the Distribution of $\mathrm{H}_{2} \mathrm{O}_{2}$ in surface waters along a meridional transect in the Eastern Atlantic. Geophvsical Research Letters 2008, 35, L03616, doi:10.1029/2007GL032555.

119. Zika, R. G.; Saltzman, E. S.; Cooper, W. J., Hydrogen Peroxide concentrations in the Peru Upwelling area. Marine Chemistrv 1985, 17, 265-275.

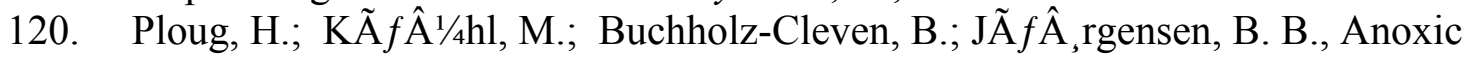
aggregates - an ephemeral phenomenon in the pelagic environment? Aquatic Microbial Ecology 1997, 13 (3), 285-294.

121. Bianchi, D.; Weber, T. S.; Kiko, R.; Deutsch, C., Global niche of marine anaerobic metabolisms expanded by particle microenvironments. Nature Geoscience 2018, 11 (4), 263-268.

122. Khademian, M.; Imlay, J. A., Escherichia coli cytochrome $c$ peroxidase is a respiratory oxidase that enables the use of hydrogen peroxide as a terminal electron acceptor. 2017, 114 (33), E6922-E6931.

123. Schlosser, C.; Streu, P.; Frank, M.; Lavik, G.; Croot, P. L.; Dengler, M.; Achterberg, E. P., H2S events in the Peruvian oxygen minimum zone facilitate enhanced dissolved Fe concentrations. Scientific Reports 2018, 8 (1), 12642.

124. Jacox, M. G.; Edwards, C. A., Effects of stratification and shelf slope on nutrient supply in coastal upwelling regions. J. Geophvs. Res. 2011, 116 (C3), C03019. 
125. Chen, C.; Thompson, A., Ferrous Iron Oxidation under Varying pO2 Levels: The Effect of Fe(III)/Al(III) Oxide Minerals and Organic Matter. Environmental Science \& Technologv 2018, 52 (2), 597-606.

126. Park, B.; Dempsey, B. A., Heterogeneous Oxidation of Fe(II) on Ferric Oxide at Neutral $\mathrm{pH}$ and a Low Partial Pressure of $\mathrm{O} 2 \uparrow$. Environmental Science \& Technologv 2005, 39 (17), 6494-6500.

127. Heller, M. I.; Lam, P. J.; Moffett, J. W.; Till, C. P.; Lee, J. M.; Toner, B. M.; Marcus, M. A., Accumulation of Fe oxyhydroxides in the Peruvian oxygen deficient zone implies non-oxygen dependent Fe oxidation. Geochimica et Cosmochimica Acta 2017, 211, 174-193.

128. Jacquot, J. E.; Kondo, Y.; Knapp, A. N.; Moffett, J. W., The speciation of copper across active gradients in nitrogen-cycle processes in the eastern tropical South Pacific. Limnol. Oceanogr. 2013, 58 (4), 1387-1394.

129. Scholz, F.; Löscher, C. R.; Fiskal, A.; Sommer, S.; Hensen, C.; Lomnitz, U.; Wuttig, K.; Göttlicher, J.; Kossel, E.; Steininger, R.; Canfield, D. E., Nitrate-dependent iron oxidation limits iron transport in anoxic ocean regions. Earth and Planetarv Science Letters 2016, 454, 272-281.

130. Hedrich, S.; Schlömann, M.; Johnson, D. B., The iron-oxidizing proteobacteria. Microbiology 2011, 157 (6), 1551-1564.

131. Field, E. K.; Kato, S.; Findlay, A. J.; MacDonald, D. J.; Chiu, B. K.; Luther, G. W.; Chan, C. S., Planktonic marine iron oxidizers drive iron mineralization under lowoxygen conditions. 2016, 14 (5), 499-508.

132. Croot, P. L.; Streu, P.; Baker, A. R., Short residence time for iron in surface seawater impacted by atmospheric dry deposition from Saharan dust events. Geophysical Research Letters 2004, 31, L23S08, doi:10.1029/2004GL020153.

133. Matthews, R. W., The radiation chemistry of aqueous ferrous sulfate solutions at natural $\mathrm{pH}$. Australian Journal of Chemistrv 1983, 36, 1305-1317.

134. Rush, J. D.; Bielski, B. H. J., Pulse Radiolytic Studies of $\mathrm{HO}_{2} / \mathrm{O}_{2}{ }^{-}$with $\mathrm{Fe}(\mathrm{II}) / \mathrm{Fe}(\mathrm{III})$ Ions. The reactivity of $\mathrm{HO}_{2} / \mathrm{O}_{2}{ }^{-}$with Ferric Ions and Its Implication on the Occurrence of the Haber-Weiss Reaction. Journal of Phvsical Chemistrv 1985, 89, 50625066.

135. Rush, J. D.; Koppenol, W. H., The reaction between ferrous polyaminocarboxylate complexes and hydrogen peroxide: An investigation of the reaction intermediates by stopped flow spectrophotometry. Journal of Inorganic Biochemistrv 1987, 29 (3), 199-215.

136. Kopf, S. H.; Henny, C.; Newman, D. K., Ligand-Enhanced Abiotic Iron Oxidation and the Effects of Chemical versus Biological Iron Cycling in Anoxic Environments. Environmental Science \& Technologv 2013, 47 (6), 2602-2611.

137. Tai, Y.-L.; Dempsey, B. A., Nitrite reduction with hydrous ferric oxide and Fe(II): Stoichiometry, rate, and mechanism. Water Research 2009, 43 (2), 546-552.

138. Chiu, B. K.; Kato, S.; McAllister, S. M.; Field, E. K.; Chan, C. S., Novel Pelagic Iron-Oxidizing Zetaproteobacteria from the Chesapeake Bav Oxic-Anoxic Transition Zone. 2017, 8 (1280). 
1 Table 1: abiotic and biotic Fe(II) oxidation rates (in seawater unless noted)

\begin{tabular}{|c|c|c|c|c|c|c|}
\hline Oxidant & Stoichiometry & Rate Law & Temperature & $\mathbf{p H}$ & Rate $\left(k_{\text {app }}\right) \mathrm{Fe}(\mathrm{II})$ & Reference \\
\hline $\mathrm{O}_{2}$ & $\sim 4: 1$ & $\begin{array}{l}-k[\mathrm{Fe}(\mathrm{II})]_{\mathrm{d}}\left[\mathrm{O}_{2}\right] \\
-k[\mathrm{Fe}(\mathrm{II})]_{\mathrm{d}}\left[\mathrm{O}_{2}\right]\left[\mathrm{OH}^{-}\right]^{2}\end{array}$ & $13^{\circ} \mathrm{C}, 34.9 \mathrm{~S}$ & 7.6 & $\begin{array}{l}1.2 \times 10^{-8} \mathrm{~s}^{-1} @ 30 \mathrm{nM} \mathrm{O}_{2} \\
\sim 1 \times 10^{-8} \mathrm{~s}^{-1} @ 30 \mathrm{nM} \mathrm{O}_{2}\end{array}$ & $\begin{array}{l}42 \\
83 \\
84\end{array}$ \\
\hline $\mathrm{H}_{2} \mathrm{O}_{2}$ & $\sim 2: 1$ & $-k[\mathrm{Fe}(\mathrm{II})]_{\mathrm{d}}\left[\mathrm{H}_{2} \mathrm{O}_{2}\right]$ & $13^{\circ} \mathrm{C}$ & 7.6 & $2.74 \times 10^{-5} \mathrm{~s}^{-1} @ 1 \mathrm{nM} \mathrm{H}_{2} \mathrm{O}_{2}$ & 41 \\
\hline $\mathrm{O}_{2}^{-}$ & $1: 1$ & $-k[\mathrm{Fe}(\mathrm{II})]_{\mathrm{d}}\left[\mathrm{O}_{2}^{-}\right]$ & $25^{\circ} \mathrm{C}$ & 7.6 & $1 \times 10^{7} M^{-1} s^{-1}(a)$ & 133,134 \\
\hline $\mathrm{OH}$ & $1: 1$ & $-k[\mathrm{Fe}(\mathrm{II})]_{\mathrm{d}}[\mathrm{OH}]$ & $25^{\circ} \mathrm{C}$ & 7.6 & $3 \times 10^{8} M^{-1} s^{-1}(b)$ & 135 \\
\hline$\left[\mathrm{NO}_{3}{ }^{-}\right]$ & $\sim 2: 1$ & $-k[\mathrm{Fe}(\mathrm{II})]_{\mathrm{d}}\left[\mathrm{NO}_{3}^{-}\right]$ & $20^{\circ} \mathrm{C}$ & 8 & $1.5 \times 10^{-9} \mathrm{~s}^{-1} @ 30 \mu \mathrm{M} \mathrm{NO}_{3}^{-}$ & 88 \\
\hline$\left[\mathrm{NO}_{2}^{-}\right]$ & $\sim 2: 1$ & $-2 k[\mathrm{Fe}(\mathrm{II})]_{\mathrm{d}}\left[\mathrm{NO}_{2}^{-}\right]$ & $25^{\circ} \mathrm{C}$ & 7 & $6.67 \times 10^{-9} \mathrm{~s}^{-1} @ 1 \mu \mathrm{M} \mathrm{NO}_{2}^{-}$ & 136 \\
\hline$\left[\mathrm{NO}_{2}^{-}\right], \mathrm{HFO}$ & $\sim 2: 1$ & $-k[\mathrm{Fe}(\mathrm{II})]_{\mathrm{d}}[\mathrm{Fe}(\mathrm{II})]_{\mathrm{s}}\left[\mathrm{NO}_{2}{ }^{-}\right]$ & $26^{\circ} \mathrm{C}$ & 6.8 & $\sim 4 \times 10^{-15} \mathrm{M} \mathrm{s}^{-1}$ & 137 \\
\hline ZPB CP8(c) & $1: 1$ & $-k[$ cell $]$ & $22^{\circ} \mathrm{C}$ & 7.1 & $1.84 \times 10^{-18} \mathrm{~mol} \mathrm{cell}^{-1} \mathrm{~s}^{-1}$ & 131 \\
\hline
\end{tabular}

(a) Bimolecular rate constant $k$, there are no estimates for steady state $\mathrm{O}_{2}^{-}$in the core of an OMZ at present, presumably less than 1 pM.

(b) Bimolecular rate constant $k$, there are no estimates for steady state $\mathrm{OH}$ in the core of an $\mathrm{OMZ}$ at present, presumably less than $1 \mathrm{fM}$.

(c) (c) ZPB CP8 = Zetaproteobacteria, Mariprofundus ferrinatatus CP-8 ${ }^{138}$ 
6 Table 2: Fe(II) sediment fluxes estimated from M77/1 water column data using a single layer 1D model.

\begin{tabular}{|c|c|c|c|c|c|c|}
\hline Station & $\begin{array}{c}\text { Water } \\
\text { Depth } \\
\text { (m) }\end{array}$ & $\begin{array}{c}\text { Sediment }^{\mathrm{a}} \\
\text { flux } \\
\left(\mathrm{mmol} \mathrm{m}^{-2} \mathbf{y}^{-1}\right)\end{array}$ & $\begin{array}{c}\text { Integrated } \\
\text { Fe(II) }{ }^{\mathbf{b}} \\
\text { Water Column } \\
\left.(\mu \mathrm{mol} \mathrm{m})^{-2}\right)\end{array}$ & $\begin{array}{c}\mathrm{C}_{0}{ }^{\mathrm{c}} \\
{[\mathrm{Fe}(\mathrm{II})]} \\
\mathrm{nM}\end{array}$ & $\begin{array}{c}\text { Oxidation }^{\mathbf{d}} \\
\text { Rate } \\
\left(\mathrm{s}^{-1}\right)\end{array}$ & $\begin{array}{c}K_{z} \\
\left(\mathrm{~cm}^{2} \mathrm{~s}^{-1}\right)\end{array}$ \\
\hline $\begin{array}{c}\text { 532/MUC } \\
47 \& 48\end{array}$ & 143 & n.d. & 219.4 (to $60 \mathrm{~m}$ ) & $13.5 \pm 1.2$ & n.d. & n.d. \\
\hline $\begin{array}{c}\text { 556/MUC } \\
54 \& 55 \text { (deeper) }\end{array}$ & 315 & 0.59 & 281.2 (to $130 \mathrm{~m}$ ) & $2.4 \pm 0.4$ & $6.7 \pm 0.7 \times 10^{-8}$ & $9.0 \pm 1.1$ \\
\hline 569/MUC 66 & 185 & 3.48 & 1383.5 (to $50 \mathrm{~m}$ ) & $18 \pm 2.1$ & $8.0 \pm 0.8 \times 10^{-8}$ & $4.7 \pm 1.4$ \\
\hline $\begin{array}{c}\text { 575/BIGO T4 \& } \\
\text { T5 }\end{array}$ & 304 & $\begin{array}{l}8.44(\mathrm{~T} 4) \\
12.95(\mathrm{~T} 5)\end{array}$ & 1374.4 & $21.3 \pm 2.0$ & $1.9 \pm 0.2 \times 10^{-7}$ & $8.1 \pm 1.8$ \\
\hline 599/MUC 61 & 295.5 & $5.39^{f}$ & 198.1 (to $60 \mathrm{~m}$ ) & $8.7 \pm 0.4$ & $8.6 \pm 0.8 \times 10^{-7}$ & $4.5 \pm 0.4$ \\
\hline 618/MUC 83 & 153.8 & $59.2^{\mathrm{f}}$ & 1904.8 & $35.5 \pm 4.0$ & $9.9 \pm 1 \times 10^{-7}$ & $28.4 \pm 7.2$ \\
\hline
\end{tabular}


8 aData from Noffke (2012), from flux chamber or porewater diffusive flux estimates from a MUC (Multicorer) or BIGO (Biogeochemical

9 Observatory) Lander. ${ }^{\mathrm{b}}$ Trapezoidal integration. ${ }^{\mathrm{c} U}$ sing the 1-layer model as described above. ${ }^{\mathrm{d}}$ Oxidation rate calculated using equation $\mathrm{x}$ with the

10 flux as estimated from the sediment core data. ${ }^{e}$ Using the 2-layer model as described in section x.y.z ${ }^{\mathrm{f}}$ Christian Hensen (GEOMAR) personal 11 communication. 
Figure Legends

Figure 1: Station locations for Fe(II) water column profiles occupied during M77-1

(red triangles). The location of stations were Fe(II) data was reported in earlier works are also shown: purple hexagons - Hong and Kester ${ }^{65}$, white diamonds - Vedamati et al. ${ }^{53}$. The location of the IMARPE time series station S4 is also shown in gray ${ }^{115}$. Bathymetry contours are shown for 50, 100, 200, 300 (blue), 400, 500, 1000, 1500 and $2000 \mathrm{~m}$.

Figure 2: Monthly Chlorophyll - CMEMS (top, left) August 2008, (top, right)

September 2008, (bottom, left) October 2008 and (bottom, right) November 2008.

[Data product Global Ocean Chlorophyll (Copernicus-GlobColour) from Satellite Observations - Reprocessed]

Figure 3: Station 532 (left) Potential temperature $(\theta$, red)) and salinity (S, blue), (centre) Nitrite (brown squares), Fe(II) (black circles), the 1layer fit to the Fe(II) profile is shown in green, (right) Dissolved Oxygen (red) and $\mathrm{H}_{2} \mathrm{O}_{2}$ (blue circles).

Figure 4: Station 599 (left) Potential temperature $(\theta$, red)) and salinity (S, blue), (centre) Fe(II) (black circles), the 1layer fit to the Fe(II) profile is shown in green, (right) Dissolved Oxygen (red) and $\mathrm{H}_{2} \mathrm{O}_{2}$ (blue circles).

Figure 5: Station 618 (left) Potential temperature $(\theta$, red)) and salinity (S, blue), (centre) Fe(II) (black circles), the 2layer fit to the Fe(II) profile is shown in green, (right) Dissolved Oxygen (red) and $\mathrm{H}_{2} \mathrm{O}_{2}$ (blue circles). 


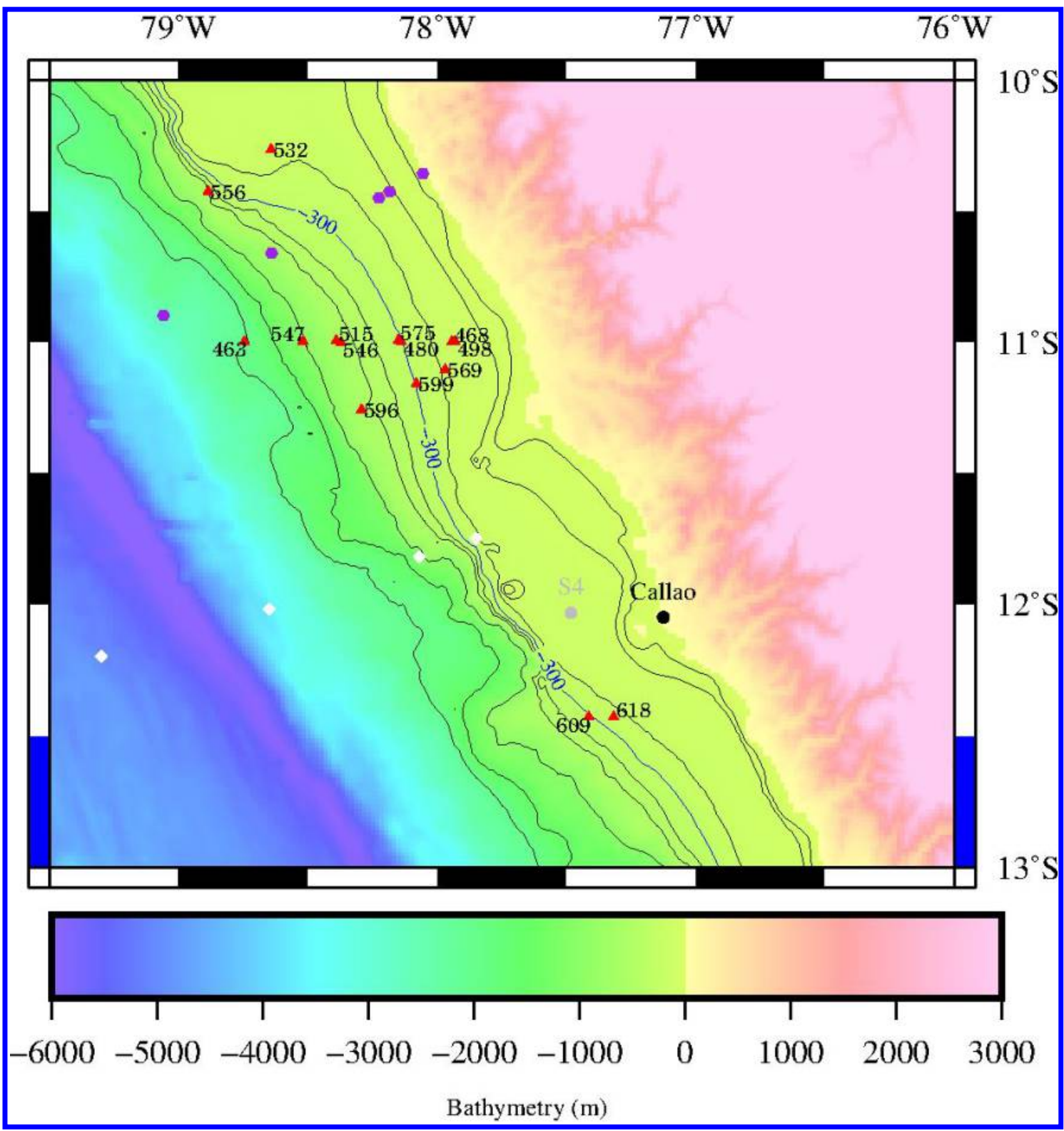

Figure 1: Station locations for Fe(II) water column profiles occupied during M77-1

(red triangles). The location of stations were Fe(II) data was reported in earlier works

are also shown: purple hexagons - Hong and Kester ${ }^{65}$, white diamonds - Vedamati

41 et al. ${ }^{53}$. The location of the IMARPE time series station S4 is also shown in gray ${ }^{115}$.

42 Bathymetry contours are shown for 50, 100, 200, 300 (blue), 400, 500, 1000, 1500 and $2000 \mathrm{~m}$. 


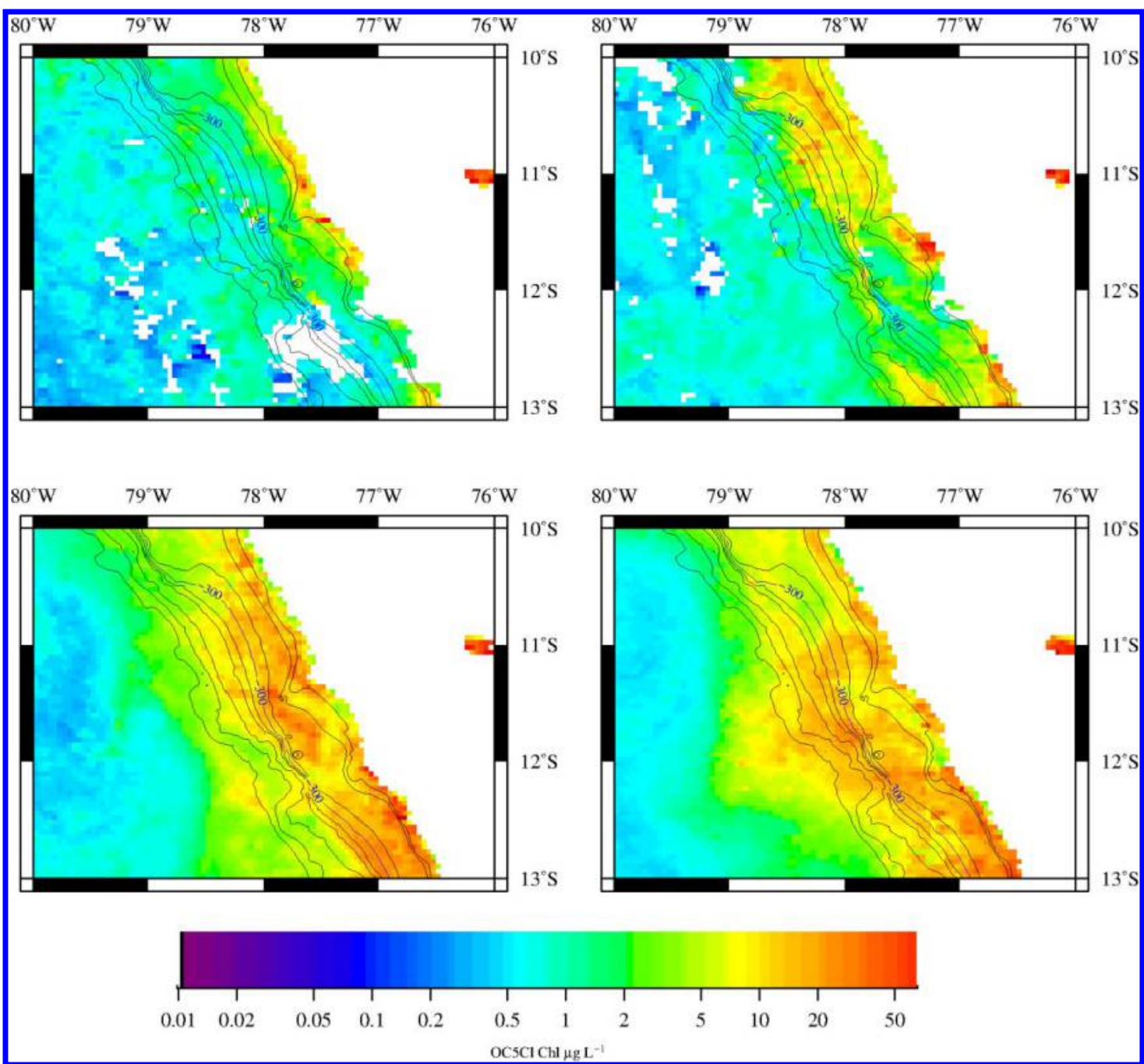

Figure 2: Monthly Chlorophyll - CMEMS (top, left) August 2008, (top, right)

September 2008, (bottom, left) October 2008 and (bottom, right) November 2008.

[Data product Global Ocean Chlorophyll (Copernicus-GlobColour) from Satellite 
50

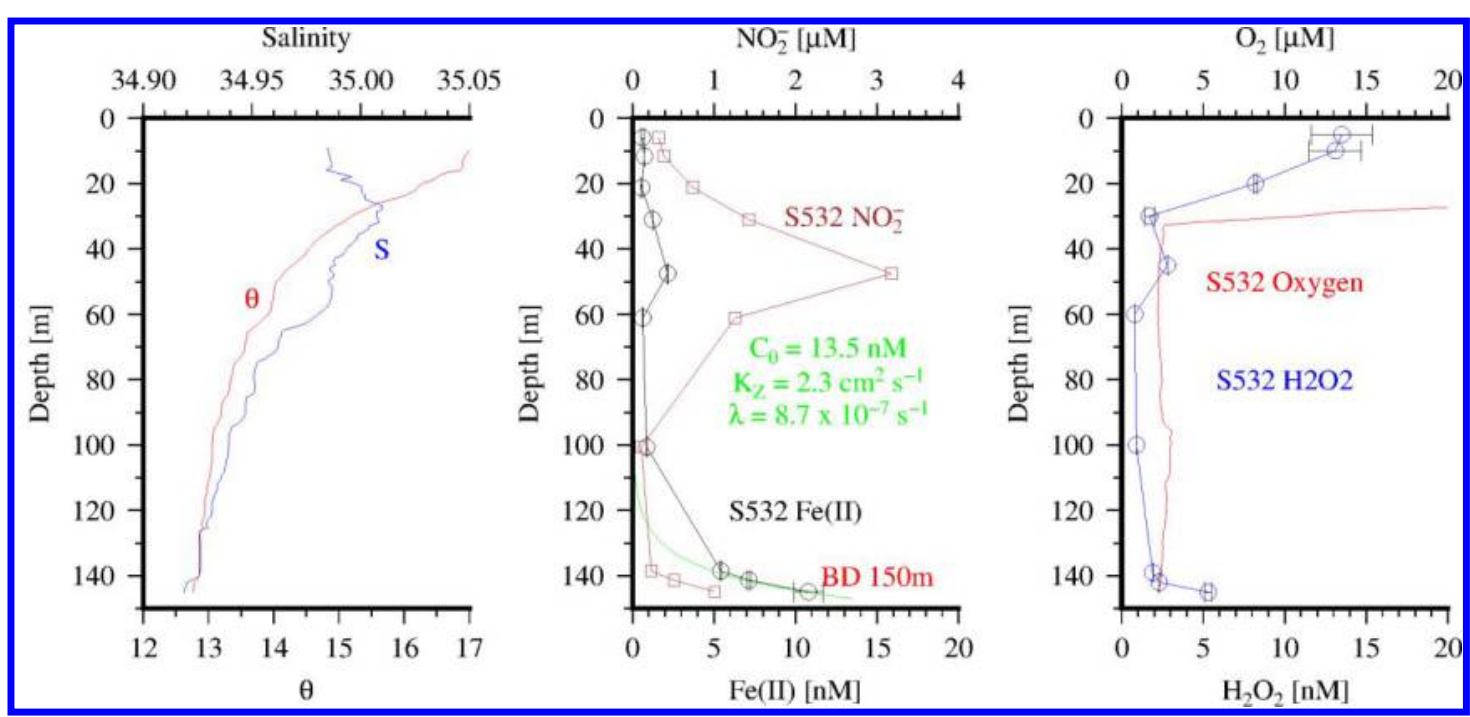

52 Figure 3: Station 532 (left) Potential temperature $(\theta$, red)) and salinity (S, blue),

53 (centre) Nitrite (brown squares), $\mathrm{Fe}(\mathrm{II})$ (black circles), the 1layer fit to the Fe(II)

54 profile is shown in green, (right) Dissolved Oxygen (red) and $\mathrm{H}_{2} \mathrm{O}_{2}$ (blue circles). 

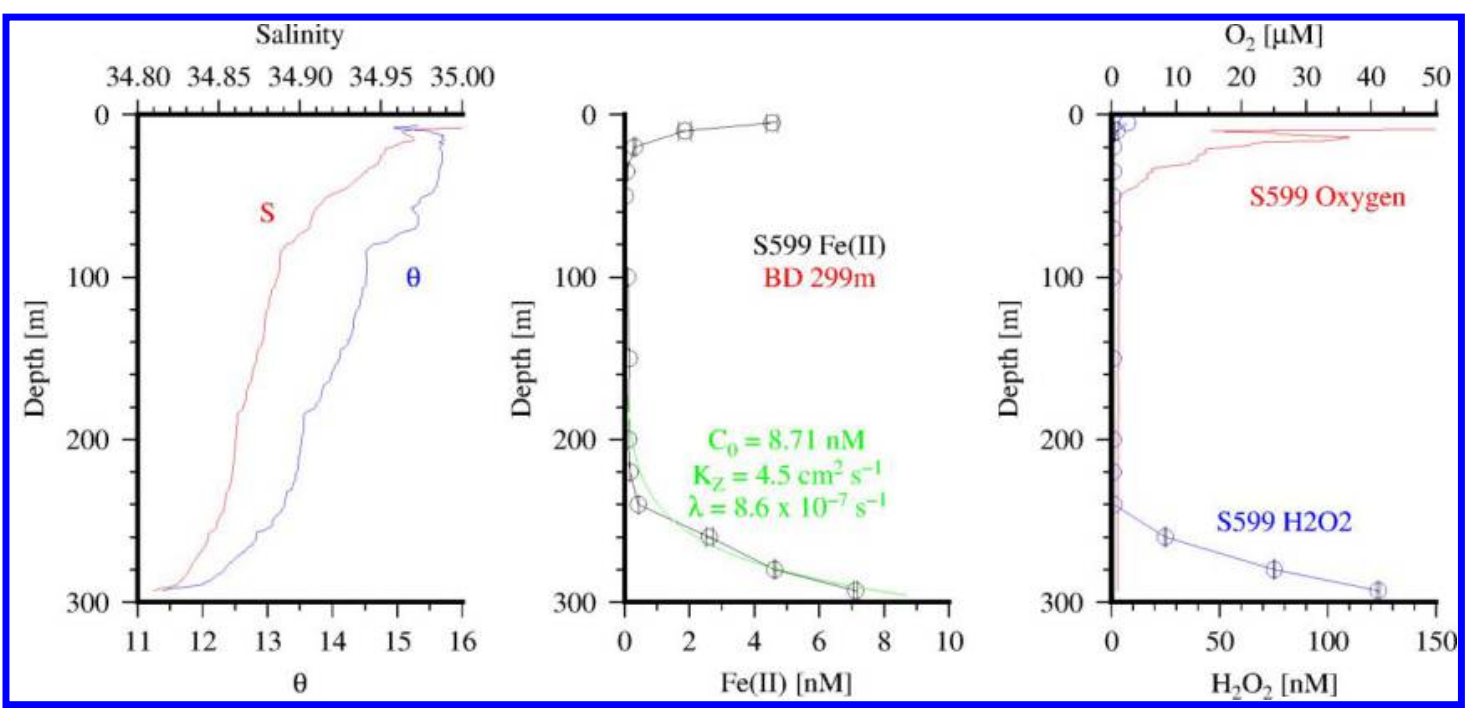

56 Figure 4: Station 599 (left) Potential temperature $(\theta$, red)) and salinity (S, blue),

57 (centre) $\mathrm{Fe}(\mathrm{II})$ (black circles), the 1layer fit to the $\mathrm{Fe}(\mathrm{II})$ profile is shown in green, 58 (right) Dissolved Oxygen (red) and $\mathrm{H}_{2} \mathrm{O}_{2}$ (blue circles). 
60

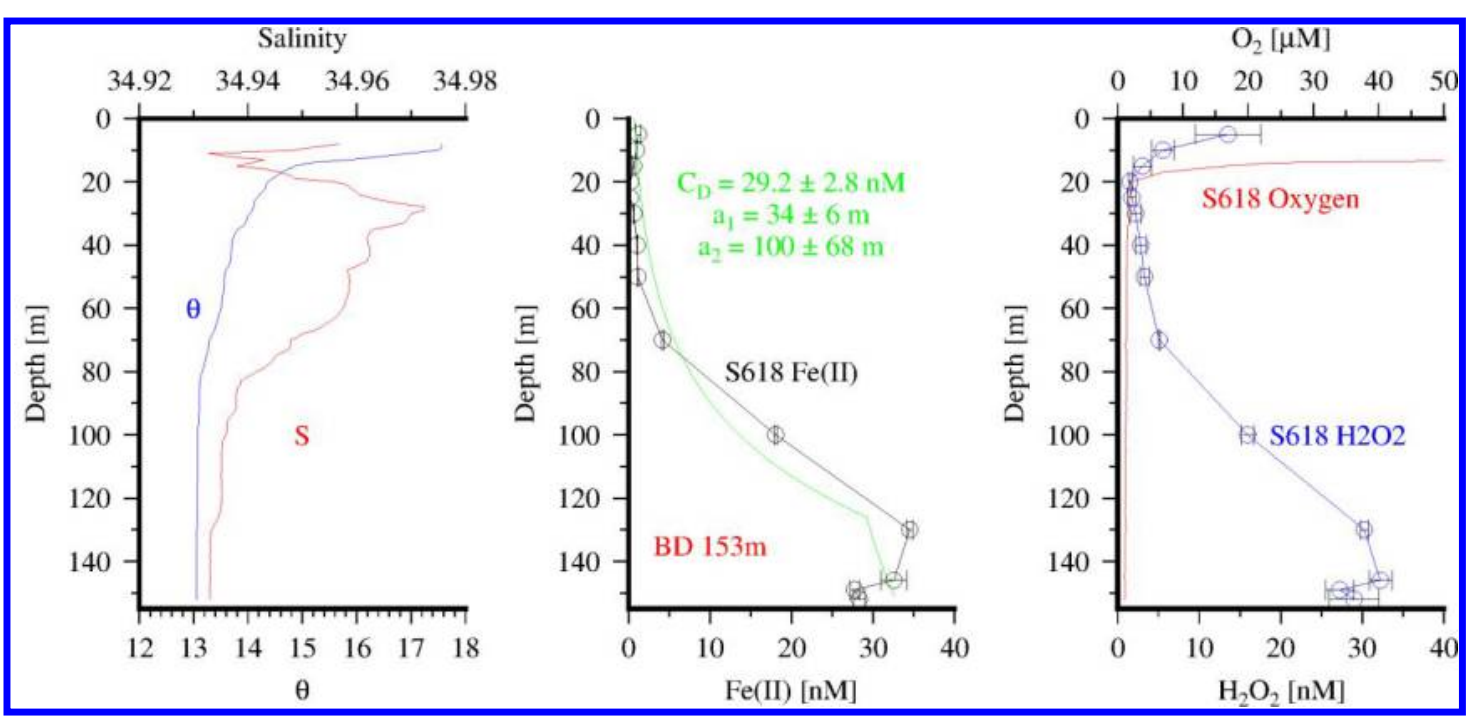

62 Figure 5: Station 618 (left) Potential temperature $(\theta$, red)) and salinity (S, blue),

63 (centre) $\mathrm{Fe}(\mathrm{II})$ (black circles), the 2layer fit to the Fe(II) profile is shown in green,

64 (right) Dissolved Oxygen (red) and $\mathrm{H}_{2} \mathrm{O}_{2}$ (blue circles).

65 


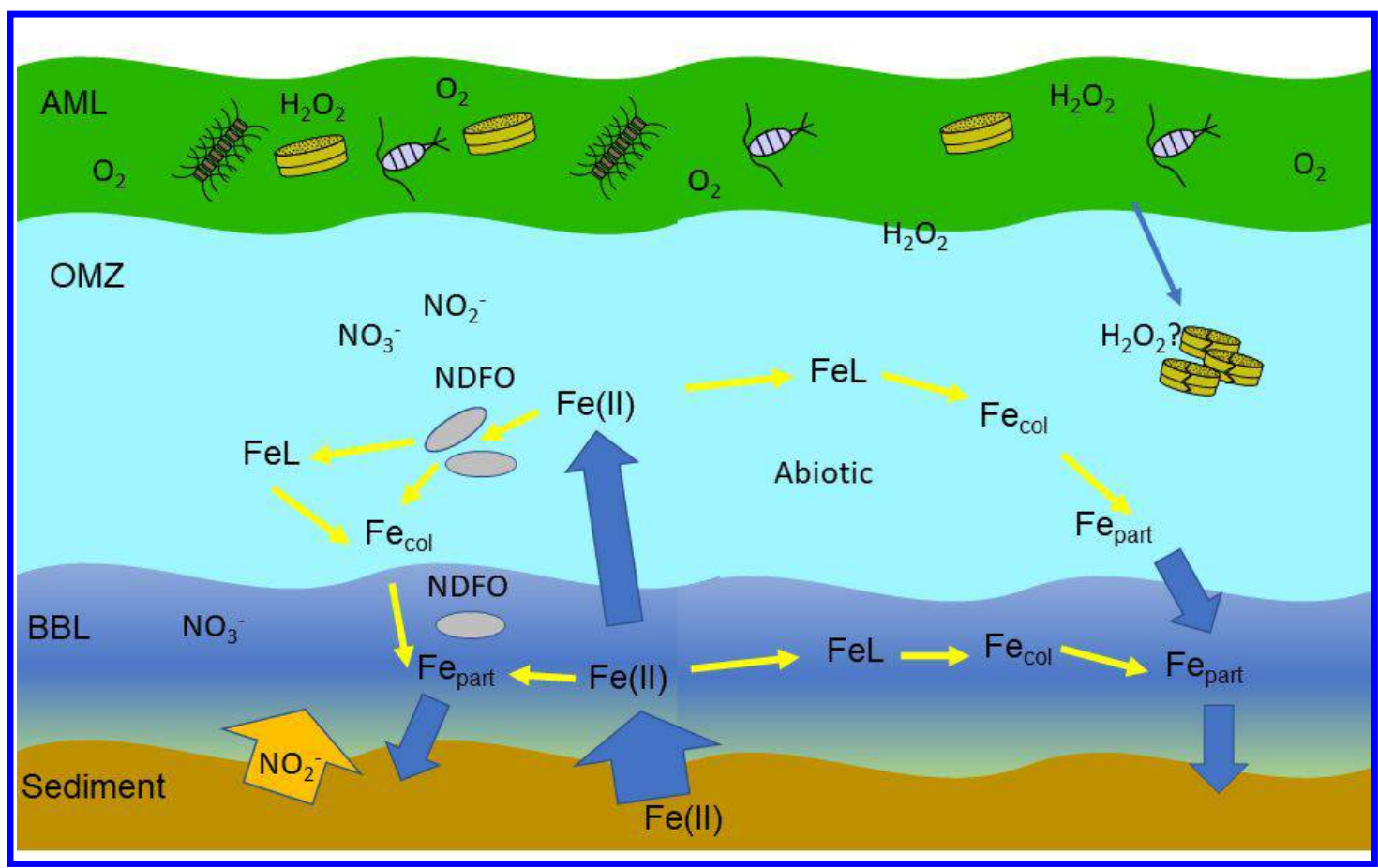

For TOC only

68 


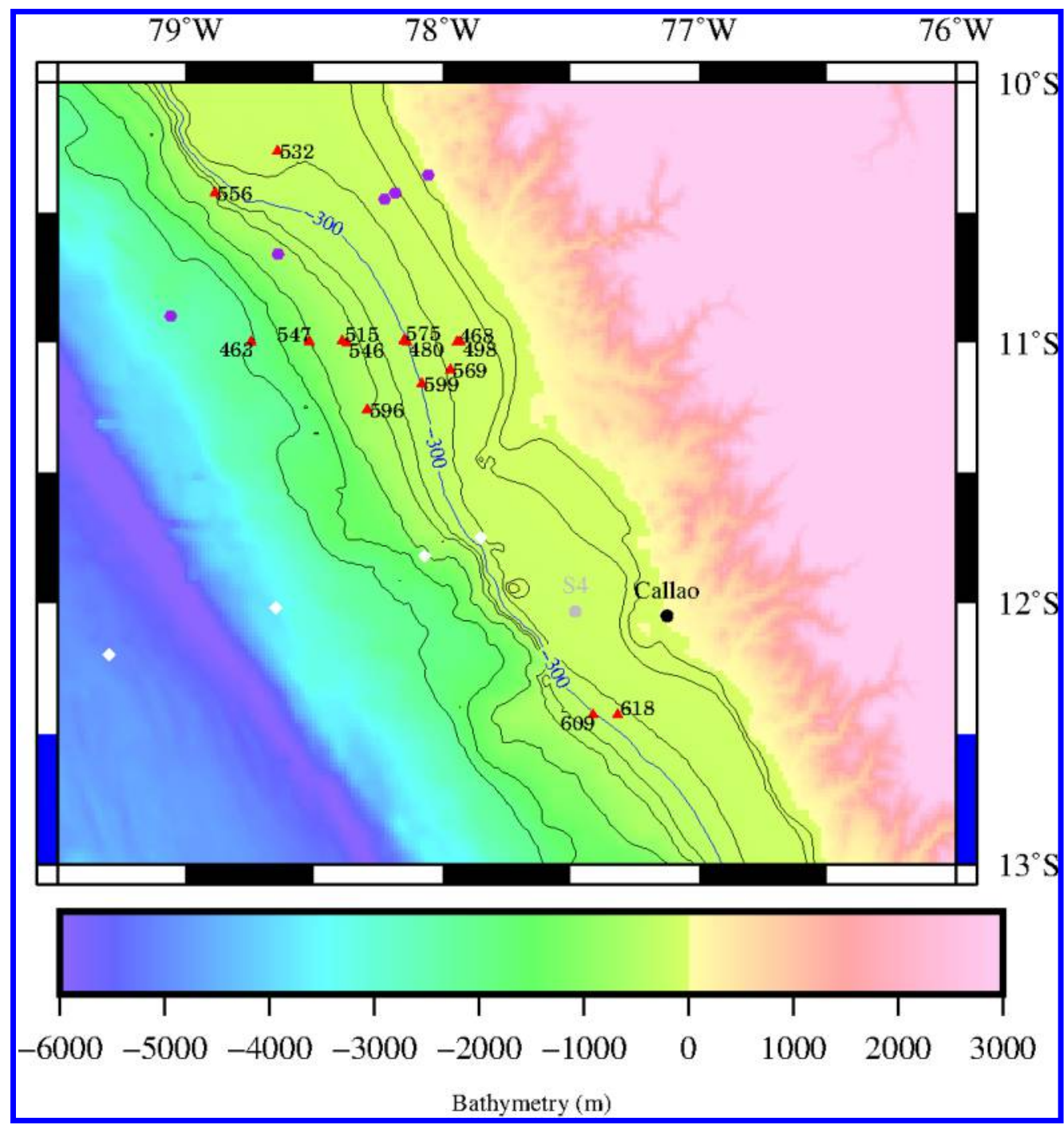

$88 \times 93 \mathrm{~mm}(300 \times 300$ DPI $)$ 


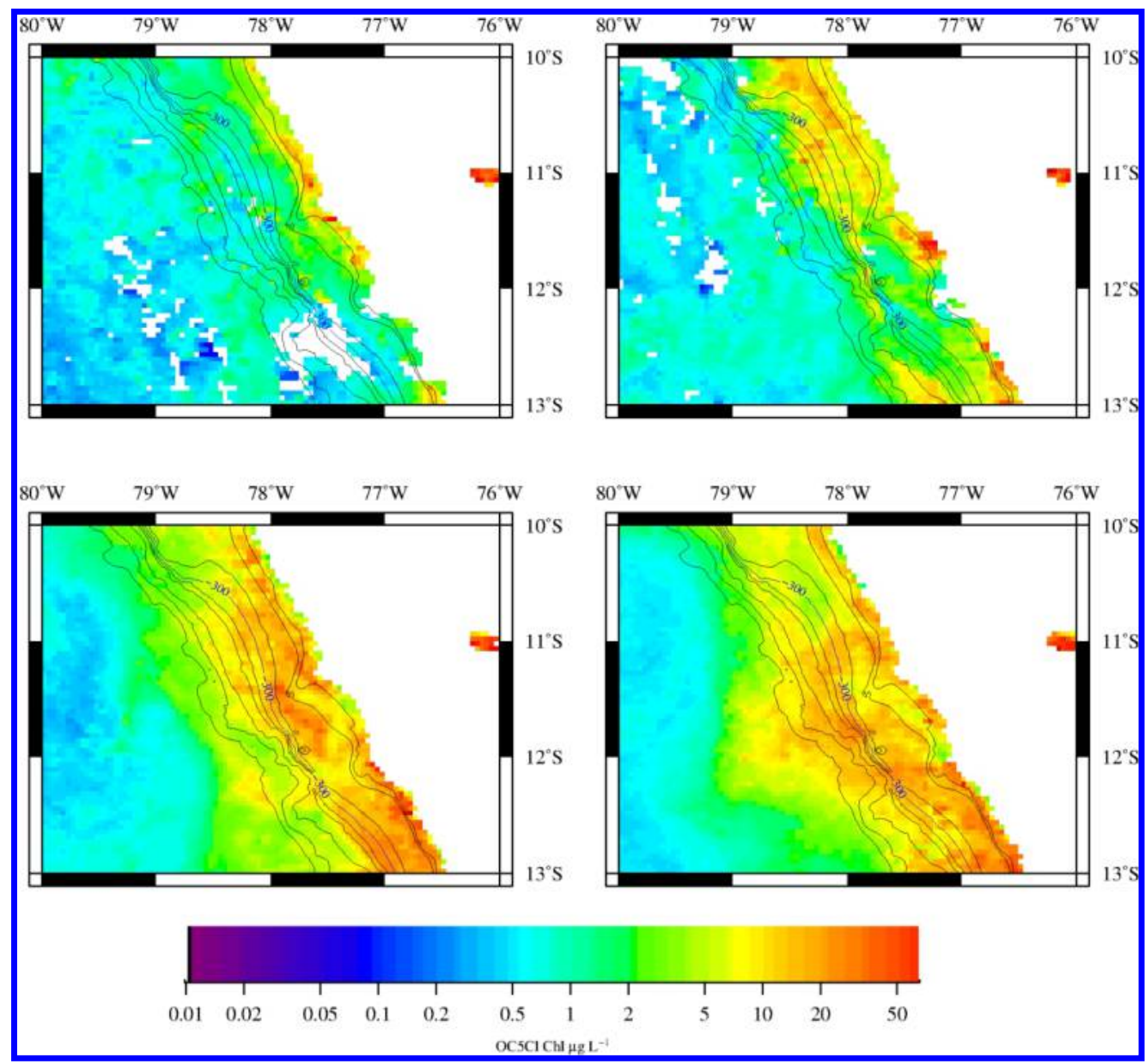

$155 \times 144 \mathrm{~mm}(300 \times 300 \mathrm{DPI})$ 


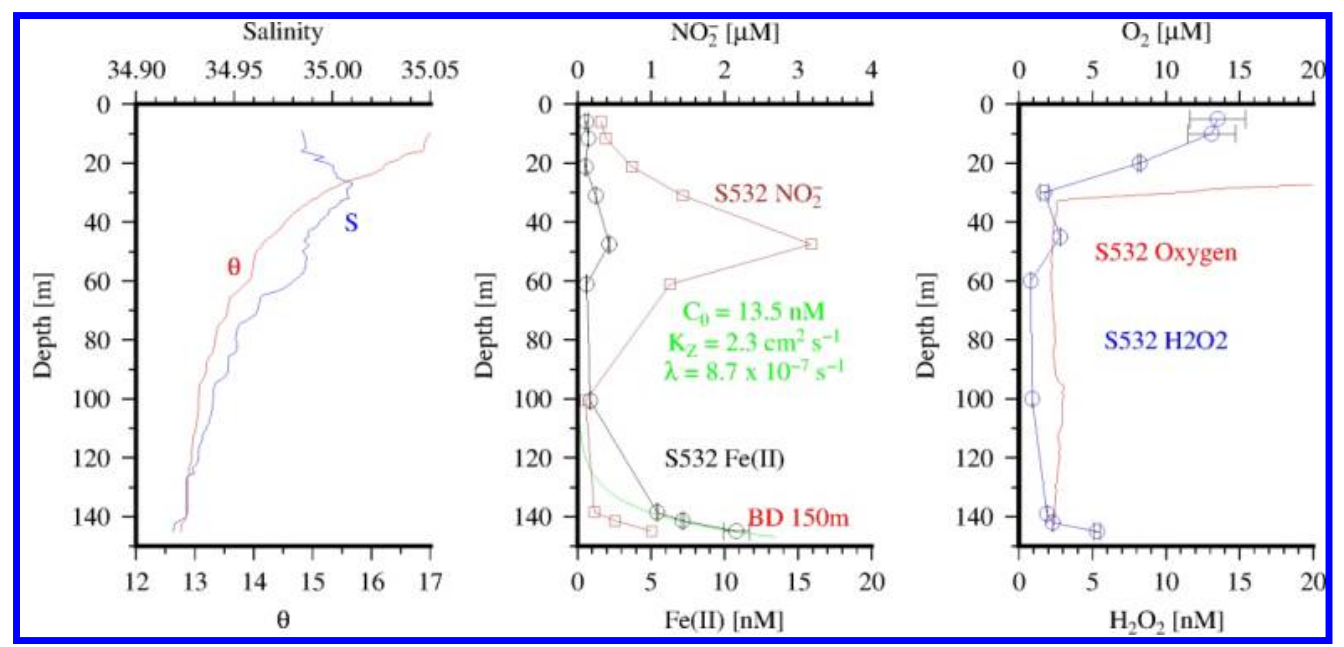

$177 \times 83 \mathrm{~mm}(300 \times 300 \mathrm{DPI})$ 


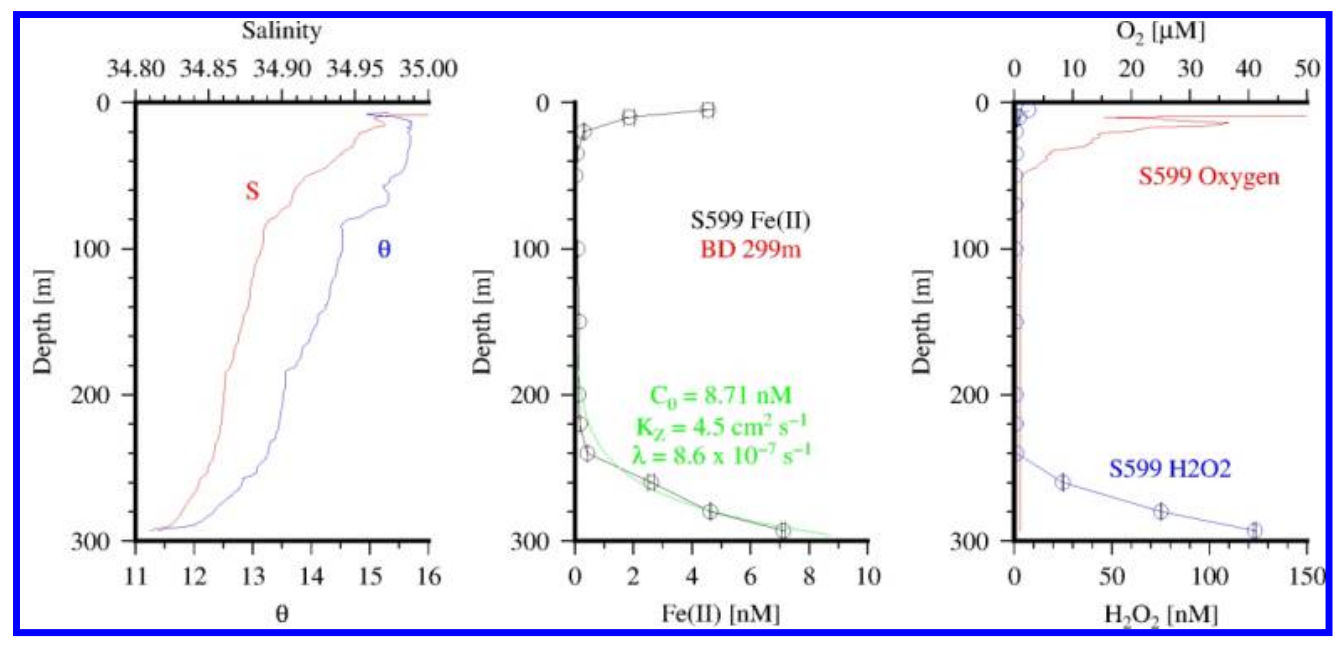

$177 \times 83 \mathrm{~mm}(300 \times 300 \mathrm{DPI})$ 


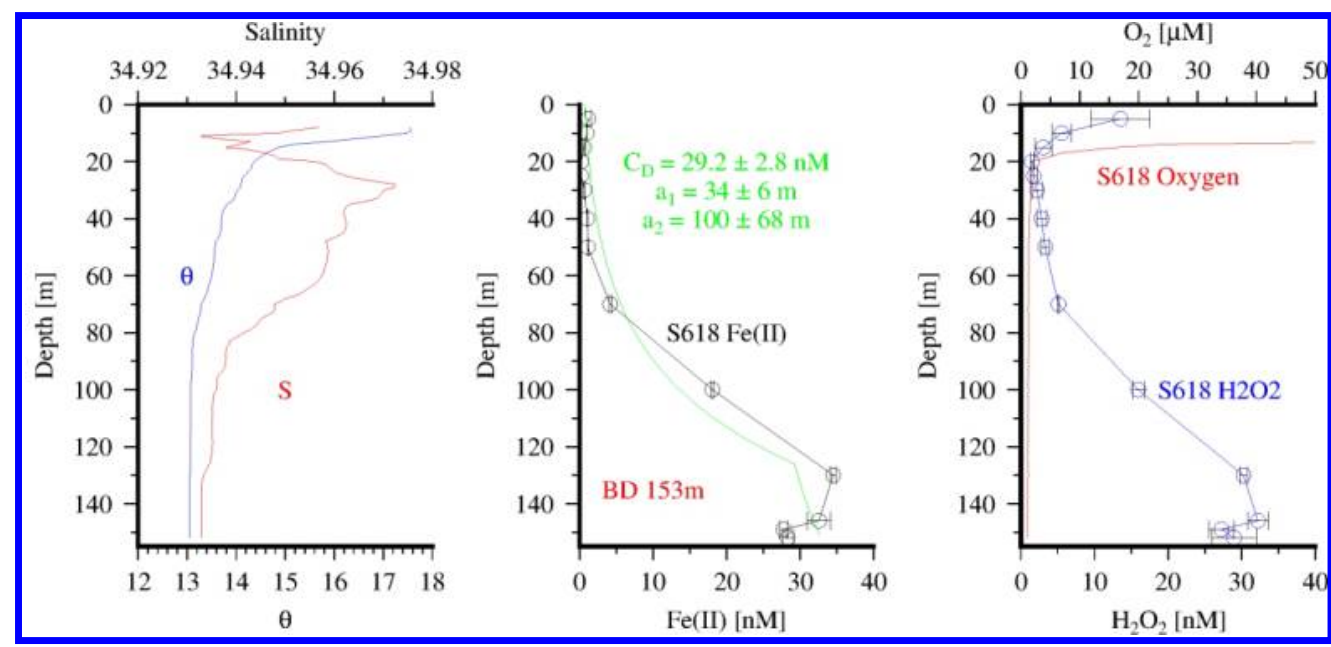

$177 \times 83 \mathrm{~mm}(300 \times 300$ DPI $)$ 


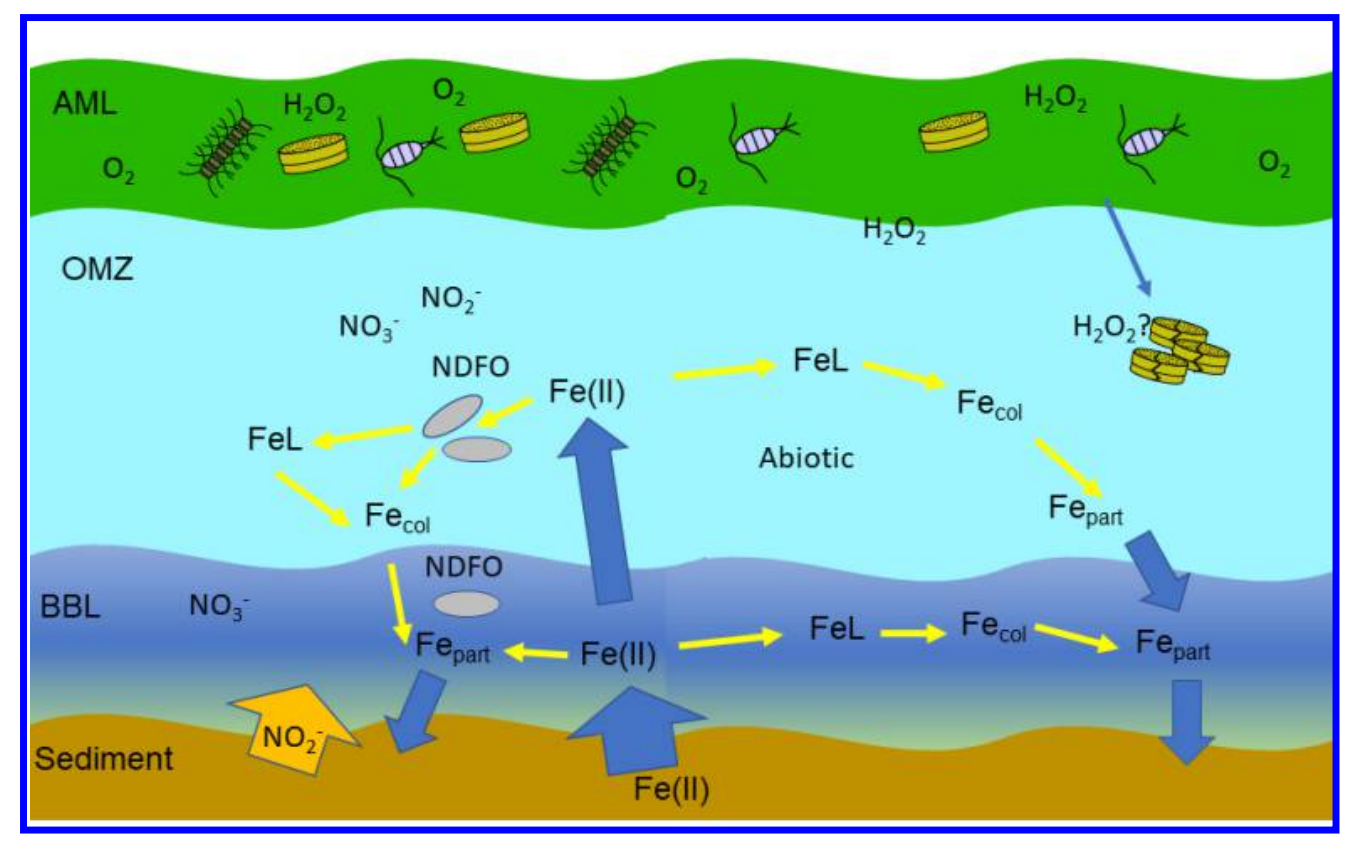

